\title{
Lithofacies and basinal development of the type 'Etcheminian Series' (Lower Cambrian Ratcliffe Brook Formation), Saint John area, southern New Brunswick
}

\author{
S.K. Tanoli* and R.K. Pickerill \\ Department of Geology, University of New Brunswick, Fredericton, New Brunswick E3B 5A3, Canada
}

Date Received October 30, 1989
Date Accepted January 31,1990

The Ratcliffe Brook Formation of the Saint John Group of the Avalon Terrane of New Brunswick forms the type Etcheminian Series for sub-trilobitic Cambrian strata. The formation, which is of variable thickness but up to 240-265 m, consists of six lithofacies which are generally arranged in stratigraphically ascending order, and are:- RB1 basal conglomerate, RB2 rippled and non-rippled sandstone, RB3 layered siliceous claystone and fine-grained sandstone, RB4 greenish-grey chamositic sandstone and siltstone, RB5 maroon, thick-bedded, medium- to coarse-grained sandstone and conglomerate, and RB6 greenish and maroon shale, siltstone, sandstone, and volcanogenic sandstone.

Facies RB1 is interpreted to have been deposited in braid channels associated with distal portions of an alluvial fan, possibly in a coastal setting. Overlying facies are interpreted as having been deposited in transitional and shallow marine environments. Facies RB2-RB4 were deposited in a continuously deepening basin related to the early Cambrian eustatic marine transgression. Facies RB5 is subdivided into two subfacies, RB5a and RB5b, with RB5a believed to represent shallow marine foreshoreshoreface deposits and RBSb deposits formed within distributary channels on the delta plain of a prograding delta complex. Facies RB6 was deposited in a lagoon of probable uneven width and depth, and which received sediments from varied local sources.

The consider able variation in thickness and spatial development of the six lithofacies within the Saint John Basin suggest that initially the basin had an uneven topography. In early stages of the early Cambrian transgression only basin lowlands were drowned and were subject to sedimentation. Complete coverage of the basin was not accomplished until late in the development of the Ratcliffe Brook Formation with the deposition of facies RB6.

La Formation de Ratcliffe Brook (Groupe de Saint John, Lanière d'Avalon, Nouveau-Brunswick) constitue la série-type de l'Etcheminien pour les strates cambriennes sub-trilobitiques. La formation, dont l'épaisseur varie mais atteint 240 à $265 \mathrm{~m}$, comporte six lithofaciès arrangés généralement en ordre stratigraphique vers le haut et qui sont:- RB1 poudingue basal, RB2 grès avec ou sans rides, RB3 grès fin intercalé de claystone siliceux, RB4 grès et siltite chamositiques gris-vert, RB5 grès moyen à grossier et poudingue marrons en bancs épais, et RB6 shale, siltite, grès et grès volcanogénique verdâtres et marrons.

On interprète le faciès RB1 comme s'étant accumulés dans des chenaux tressés associés aux portions distales d'un cône de déjection, possiblement en milieu littoral. On interprète les faciès sus-jacents comme s'étant accumulés en milieux paralique et marin peu profond. Les faciès RB2 à RB4 se sont accumulés dans un bassin s'approfondissant de façon continue et relié à la transgression marine eustatique du début du Cambrien. On subdivise le faciès RB5 en deux sous-faciès, RB5 a et RB5b; on croit que RB5a représente des dépôts marins peu profonds d'avant-plage et d'estran, et RB5b des dépôts formés dans des chenaux de plaine deltaïque au sein d'un complexe deltaïque en cours de progradation. Le dépôt du faciès RB6 s'effectua dans une lagune dont la largeur et la profondeur variaient, et qui recevait des sédiments de sources diverses et locales.

La forte variation de l'épaisseur et du développement dans l'espace des six lithofaciès présents au sein du Bassin de Saint John suggère que la topographie initiale de ce dernier était irrégulière. Seules les basses-terres de bassin furent ennoyées et soumise à une sédimentation durant l'amorce de la transgression éocambrienne. L'inondation totale du bassin ne fut réalisée que vers la fin du développement de la Formation de Ratcliffe Brook, avec le dépôt du faciès RB6.

[Traduit par le journal]

\section{INTRODUCTION}

Redbeds of the Ratcliffe Brook Formation form the basal sequence of the sub-trilobitic Cambrian-Lower Ordovician Saint
John Group (Hayes and Howell, 1937; Tanoli, 1987; Tanoli and Pickerill, 1988), as exposed in and around the city of Saint John in southern New Brunswick (Fig. 1). This formation comprises the type 'Etcheminian Series' (=Basal Series) as proposed by

\footnotetext{
*Present address: National Centre of Excellence in Geology, University
} of Peshawar, Peshawar, Pakistan 


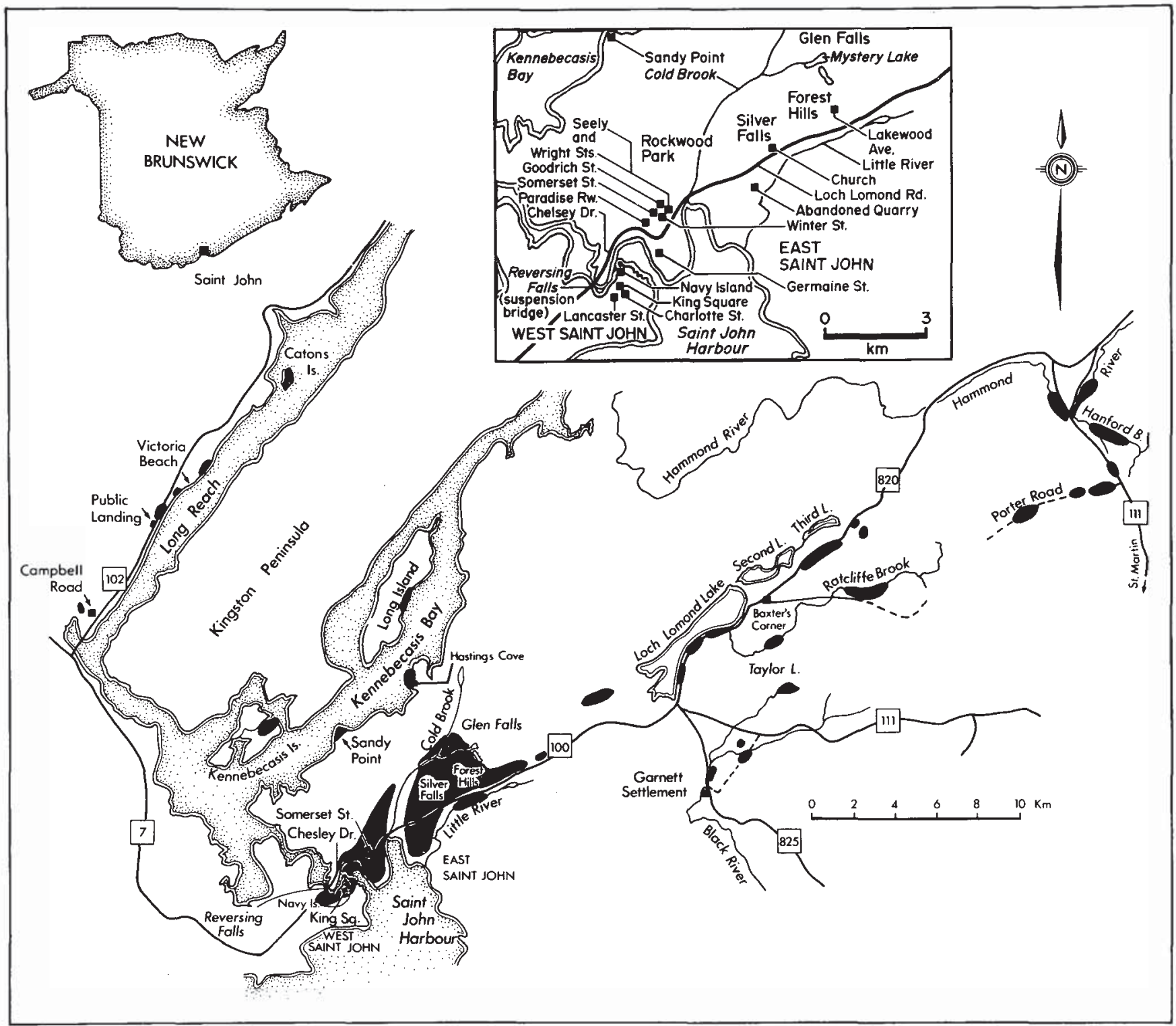

Fig. 1. Location map showing the distribution of the Saint John Group (in black) in southern New Brunswick. Inset is an expanded map of the city of Saint John illustrating locations referred to in the main text.

Matthew (1889) for the Lower Cambrian of Atlantic Canada, and eastern Massachusetts. Matthew's (1899a, 1899b, 1899c) descriptions of the pre-trilobitic faunas from this series suggests that he was dealing with an interval that was broadly similar in content and concept to the more recently proposed Tommotian Stage of the Siberian Platform and the Meishucunian Stage of the South China Platform (Landing et al., 1989). The descriptor Etcheminian Series is no longer in general use and has been renamed the Placentian Series by Landing et al. (1989). The occurrence of the agglutinated problematic form Platysolenites antiquissimus Eichwald and the hyolith "Allatheca" degeeri (Holm) within the Ratcliffe Brook Formation prompted Landing et al. (1989) to regard the sequence as correlative to the Watsonella crosbyi Zone of southeastern Newfoundland, that is the middle Placentian Series, which is Tommotian in age.

The Saint John Group, and southem New Brunswick in general, form part of the Avalon Platform of Williams (1964) or
Avalon Terrane of Williams and Hatcher (1983), remnants of which are now exposed in the southeastern United States, as far as south Carolina, in eastern Canada, and in Europe and Africa (Rast et al., 1976; O'Brien et al., 1983; Rast and Skehan, 1983). More recently Barr and White (1989) have suggested that this portion of the Avalon Terrane can be more appropriately subdivided into two terranes, the Brookville and Caledonia terranes (see later).

Despite both its historical and present-day importance, particularly with respect to debates on the Precambrian-Cambrian boundary (see Landing, 1988; Hofmann and Patel, 1989), no systematic study of lithofacies and depositional environment of the Ratcliffe Brook Formation has, until now, been undertaken. Previous speculations on the depositional environment, commonly without any detailed supportive evidence, have been extremely varied. Hayes and Howell (1937) suggested a terrestrial origin due to the absence of marine faunas and the predomi- 
nant purple-maroon-red colour of the strata. Yet earlier, both Matthew $(1889,1899$ c) and Walcott (1900) described marine fossils and trace fossils from the sequence, thus implying, at least in part, a marine origin. The presence of body fossils has not yet been reconfirmed but Hofmann and Patel (1989) have recently described a typically shallow water marine ichnoassemblage from the formation. Interestingly, the trace fossils described by Hofmann and Patel (1989), which include Helminthoidichnites tenuis Fitch, Monocraterion isp., Palaeophycus tubularis Hall, Planolites isp.,Psammichnites gigas Matthew, Subphyllochorda? isp., Taphrhelminthoida dailyi Hofmann and Patel and Taphrhelminthopsiscf.T. circularis Crimes et al., are suggestive of a late Tommotian to early Atdabanian or younger age for the strata (see Crimes, 1987). Finally, Patel (1973) and Hofmann and Patel (1989) suggested a partly terrestrial and dominantly marine origin for the sequence, an interpretation supported herein based on analysis and interpretation of the majority of available exposures.

The purpose of this paper, therefore, is to describe the lithofacies recognized by us from the Ratcliffe Brook Formation, to interpret them in terms of depositional environment and to comment on the basinal and palaeogeographic setting of this, albeit small, portion of the Avalon Terrane during the early Cambrian. Further details on the Ratcliffe Brook Formation are given by Tanoli (1987); additional sedimentological information on the Saint John Group has been presented by Tanoli and Pickerill $(1987,1988,1989)$.

\section{GEOLOGIC SETTING}

The Saint John region is underlain by and exposes an extremely complex range of volcano-sedimentary, metamorphic and plutonic rocks of considerably varying age. Despite more than 150 years of geological investigations and more recent remapping by, for example, Wardle (1978), Currie et al. (1981), Currie and Nance (1983), McCutcheon and Ruitenberg (1984) and Currie $(1984,1986)$, the stratigraphy and structure of the region are still imperfectly understood. Major structures consist of essentially non-synchronous, northeast-trending faults, high strain zones and folds (see Currie, 1986, p. 288, fig. 8). Regionally developed systematic folding is difficult to detect (Currie, 1988), though recognizable deformation is apparently of Precambrian and Carboniferous ages. Numerous north- and northwest-trending faults also cut the region.

As indicated in Figure 1, the Saint John Group is now exposed in several geographically separated areas of the region. Indeed, the principal reference sections are typically separated by faults along which there has been a long history of sinistral and latterly dextral motion (Currie, 1986). Locally, dip slip, reverse and thrust movements can also be identified. As discussed by Wardle (1978), these faults may have large displacements. However, as noted by Currie (1986), the size and age of these displacements are unknown and furthermore the general stratigraphic coherence of the region suggests that the movements did not produce large aggregate displacements. Currie (1988) has suggested that during the Cambrian and Early Ordovician the region was a rigid, tectonically stable area. Although impossible to demonstrate, we suspect, therefore, that these faults did not exert a primary control on the distribution of the Ratcliffe Brook lithofacies as described here, but may, to some indeterminate extent, be partly responsible for their present-day distribution.

The Saint John Group itself is exposed in a series of en echelon basins which south of the Kingston Peninsula (Fig. 1) trend north-northeast and to the north trend east-northeast. The southern group of basins are fault-bounded on the northwest side, in all cases with loss of their northwestern limbs (Currie, 1984). Internally the basins are intricately folded and faulted and are characterized by upright isoclinal to overturned folds. Two, or locally three, periods of approximately coaxial folding can be identified, the style of folding and its scale being essentially identical to that of local Carboniferous sequences (Currie, 1986). Cleavage is variably and heterogeneously developed; the first cleavage is essentially bedding parallel and the second represented by a fracture or crenulation cleavage (Tanoli, 1987).

The Ratcliffe Brook Formation, the basal unit of the Saint John Group, disconformably overlies volcanic, hypabyssal and sedimentary strata of the Hadrynian Coldbrook Group or unnamed upper Precambrian redbeds, termed Eocambrian redbeds by Currie $(1984,1986)$ and Tanoli et al. (1985). Exposures examined for the purposes of this paper are centred in the city of Saint John, northeast of Saint John in the Mystery Lake - Glen Falls - Forest Hills area, further northeast of Saint John in the Ratcliffe Brook and Hanford Brook areas, and finally to the northwest of Saint John in the Long Reach (Fig. 1). D. Nance (personal communication, 1989) has recorded exposures of the formation at Coleson Cove on the Lorneville Peninsula, located approximately $15 \mathrm{~km}$ southwest of Saint John, but these have not been examined by the present authors. In part this is because there the strata are severely mylonitized. Additionally, the age of the strata has been variously interpreted as Cambrian (Currie, 1984) and more recently Eocambrian (Currie, 1986, 1988).

The formation varies in thickness from a few metres in Saint John to up to 240-265 m in Hanford Brook, where the most complete exposure of the formation, designated as the parastratotype by Hayes and Howell (1937), is exposed. Lower contacts of the formation may be observed at several locations, including Charlotte Street, Somerset Street, Mystery Lake, Hanford Brook and at Campbell Road in the Long Reach; the upper contact with the overlying Glen Falls Formation is generally unexposed but may be observed at Goodrich Street where it is gradational and conformable (see Tanoli and Pickerill, 1988, fig. 5b). Measured stratigraphic logs of the principal exposures of the formation, together with facies interpretations as described below, are given in Figure 2.

\section{LITHOFACIES}

The lithofacies described here were defined from examination of the principal exposures of the formation (Fig. 2). Structural complexities and the generally poor outcrop of the formation elsewhere in the region make correlation and allocation to a specific lithofacies difficult. Nevertheless, as also noted by Hayes and Howell (1937), the relative stratigraphic position of these scattered and fragmentary outcrops can be ascertained from 


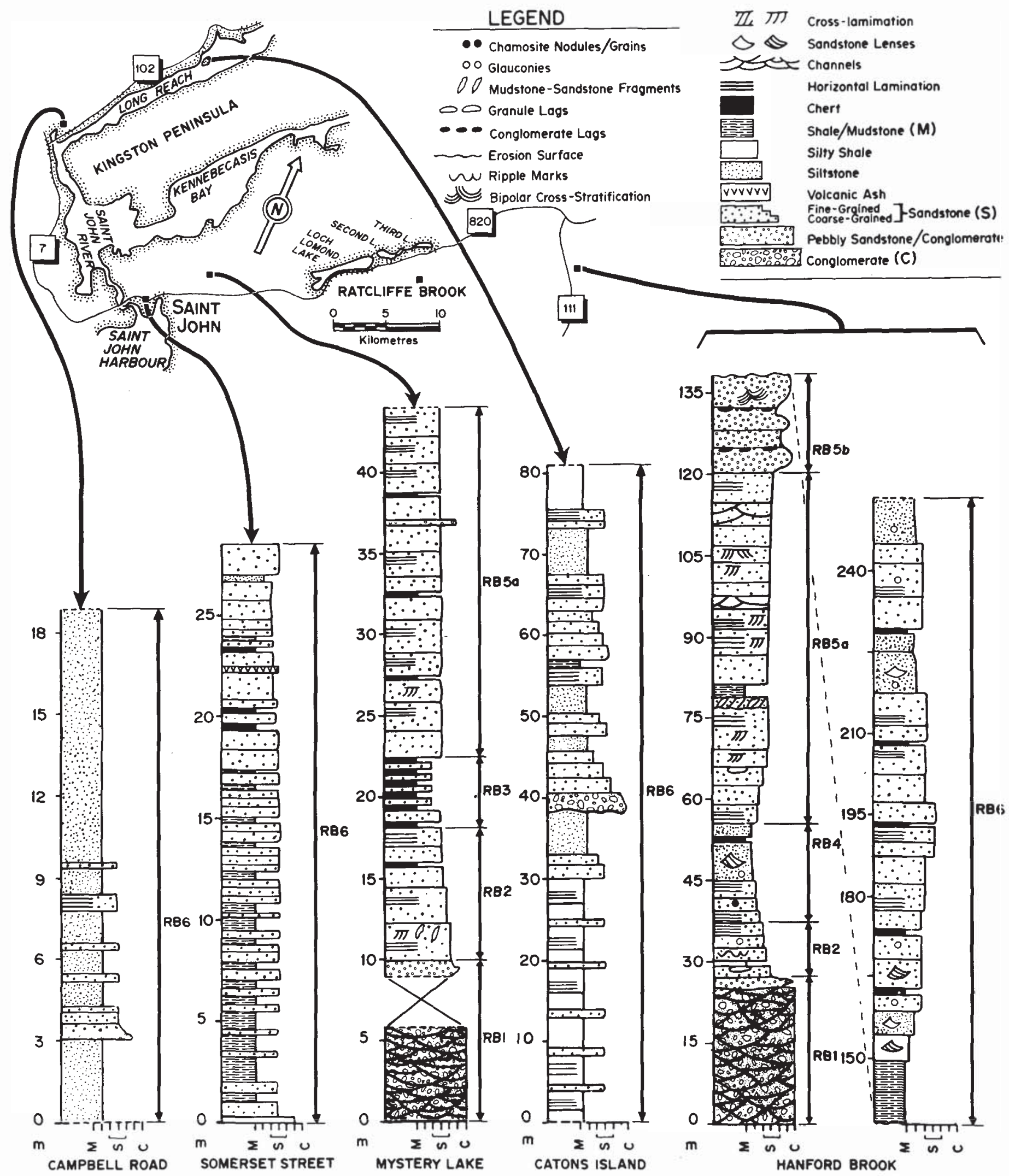

Fig. 2. Stratigraphic columns of principal reference sections of the Ratcliffe Brook Formation with lithofacies distribution. Broken lines at the base or top of individual sections indicate unexposed contacts; solid lines represent exposed contacts with, respectively, underlying or overlying stratigraphic units. 
their relationship to underlying or overlying strata.

Six lithofacies, each defined on the basis of lithology and texture, bed thickness, bedding style, sedimentary structures and relative stratigraphic position, were distinguished. These lithofacies (RB1-RB6) are generally arranged in stratigraphically ascending order, though because of their variable spatial development individual lithofacies may be absent (Fig. 2). The lithofacies are:- (1) Basal conglomerate (RB1), (2) Rippled and non-rippled sandstone (RB2), (3) Layered siliceous claystone and fine-grained sandstone (RB3), (4) Greenish-grey chamositic sandstone and siltstone (RB4), (5) Maroon, thick-bedded, medium-to coarse-grained sandstone and conglomerate (RB5a, RB5b), (6) Greenish and maroon shale, siltstone, sandstone, and volcanogenic sandstone (RB6). Hofmann and Patel (1989) recognized four informal subdivisions of the formation in Hanford Brook, termed Units I-IV, that corresponded to lithological variations. McCutcheon (1987), however, had earlier recognized six informal units (1-6) for the same sequence. With respect to the subdivisions of these authors, the lithofacies described herein correspond as follows:- RB1 is equivalent to Unit I of Hofmann and Patel and unit 1 of McCutcheon; RB2,3,4 and 5a are equivalent to Unit II of Hofmann and Patel and units
2,3 and 4 of McCutcheon; RB5b is equivalent to Unit III of Hofmann and Patel and unit 5 of McCutcheon; and RB6 is equivalent to Unit IV of Hofmann and Patel and unit 6 of McCutcheon.

With the exception of facies RB1 which is non-marine in origin, the remainder of the Ratcliffe Brook Formation, on the basis of the presence of marine body fossils (e.g., Matthew, 1889; Walcott, 1900), marine trace fossils (Hofmann and Patel, 1989) and the marine authigenic minerals, chamosite and glauconies (sensu Odin and Letolle, 1980), is regarded as marine in origin. Table 1 summarizes the essential characteristics of each lithofacies as recognized by us from the Ratcliffe Brook Formation.

\section{Facies RB1 - Basal conglomerate}

Location: Hanford Brook, Ratcliffe Brook, and Mystery Lake area (Fig. 1).

\section{Description}

Typically massive, amalgamated, reddish-brown, texturally immature, polymict, clast-supported and matrix-supported con-

Table 1. Summary of characteristics and interpreted depositional environments of facies RB1 to RB6 of the Ratcliffe Brook Formation.

\begin{tabular}{|c|c|c|c|c|c|c|c|c|c|c|c|}
\hline \multirow{2}{*}{ FACIES } & \multirow{2}{*}{ LITHOLOGY } & \multicolumn{2}{|c|}{ CONTACTS } & \multirow{2}{*}{ COLOUR } & \multirow{2}{*}{$\underset{\substack{\text { UNIT } \\
\text { THICKNESS }}}{\text { THI }}$} & \multirow{2}{*}{$\begin{array}{c}\text { BED } \\
\text { THICKNESS } \\
(\mathrm{cm})\end{array}$} & \multirow{2}{*}{$\begin{array}{c}\text { BED } \\
\text { REGULARITY }\end{array}$} & \multirow{2}{*}{$\begin{array}{l}\text { BEDDING } \\
\text { PLANES }\end{array}$} & \multirow{2}{*}{$\begin{array}{l}\text { INTERNAL } \\
\text { FEATURES }\end{array}$} & \multirow{2}{*}{$\begin{array}{l}\text { OTHER } \\
\text { CHARACTERISTICS }\end{array}$} & \multirow{2}{*}{$\begin{array}{l}\text { ENVIRONMENTAL } \\
\text { INTERPRETATION }\end{array}$} \\
\hline & & LOWER & UPPER & & & & & & & & \\
\hline RB6 & $\begin{array}{l}\text { Fine-grained } \\
\text { sandstone, } \\
\text { siltstone, } \\
\text { minor shale \& } \\
\text { conglomerate }\end{array}$ & Sharp & \begin{tabular}{|l|} 
Gradat- \\
ional to \\
the Glen \\
Falls \\
Formation
\end{tabular} & $\begin{array}{l}\text { Light } \\
\text { grey. } \\
\text { dark grey. } \\
\text { maroon }\end{array}$ & $27-110$ & 1.90 & Persistent & $\begin{array}{l}\text { Planer, } \\
\text { sharp }\end{array}$ & $\begin{array}{l}\text { Massive and } \\
\text { horizontally } \\
\text { laminated, } \\
\text { normal } \\
\text { grading }\end{array}$ & $\begin{array}{l}\text { Consists of fining } \\
\text { and thinning upward } \\
\text { volcanogenic sand- } \\
\text { stone sequences at } \\
\text { Catons Island }\end{array}$ & $\begin{array}{l}\text { Lagoon with storm } \\
\text { washovers }\end{array}$ \\
\hline RB5b & $\begin{array}{l}\text { Pebbly sand- } \\
\text { stone and } \\
\text { conglomerate }\end{array}$ & $\begin{array}{l}\text { Transit- } \\
\text { ional }\end{array}$ & Sharp & $\begin{array}{l}\text { Maroon } \\
\text { and } \\
\text { white }\end{array}$ & 18 & $40-70$ & $\begin{array}{l}\text { Indeterminate } \\
\text { but probably } \\
\text { erosive and } \\
\text { lenticular }\end{array}$ & $\begin{array}{l}\text { Probably } \\
\text { erosive }\end{array}$ & $\begin{array}{l}\text { Normal and } \\
\text { inverse } \\
\text { grading, } \\
\text { cross- } \\
\text { lamination }\end{array}$ & $\begin{array}{l}\text { Bidirectional } \\
\text { cross-lamination } \\
\text { common. Bipolar } \\
\text { cross-stratification } \\
\text { also present. } \\
\text { conglomerate lags }\end{array}$ & $\begin{array}{l}\text { Tidal reworked } \\
\text { stream distrib. } \\
\text { utary channels }\end{array}$ \\
\hline RB5a & Sandstone & $\begin{array}{l}\text { Transit- } \\
\text { ional }\end{array}$ & $\begin{array}{l}\text { Transit- } \\
\text { ional }\end{array}$ & Maroon & 63 & $20-160$ & Persistent & $\begin{array}{l}\text { Planar } \\
\text { and lag } \\
\text { cover }\end{array}$ & $\begin{array}{l}\text { Horizontal } \\
\text { lamination } \\
\text { cross. } \\
\text { lamination }\end{array}$ & $\begin{array}{l}\text { Relative to other } \\
\text { units it is mature. } \\
\text { Quartz granules } \\
\text { horizontal } \\
\text { lamination }\end{array}$ & $\begin{array}{l}\text { Nearshore shallow } \\
\text { marine.Foreshore- } \\
\text { shoreface }\end{array}$ \\
\hline RB4 & $\begin{array}{l}\text { Sandstone } \\
\text { and } \\
\text { siltstone }\end{array}$ & $\begin{array}{l}\text { Transit- } \\
\text { ional }\end{array}$ & $\begin{array}{l}\text { Transit- } \\
\text { ional }\end{array}$ & $\begin{array}{l}\text { Greenish- } \\
\text { grey and } \\
\text { maroon }\end{array}$ & 17 & $30-50$ & Persistent & Planar & $\begin{array}{l}\text { Massive or } \\
\text { horizontal } \\
\text { lamination, } \\
\text { rare cross. } \\
\text { lamination }\end{array}$ & $\begin{array}{l}\text { Thin veneer of } \\
\text { granule lag at top } \\
\text { of a few sandstone } \\
\text { beds }\end{array}$ & $\begin{array}{l}\text { Shallow } \\
\text { marine }\end{array}$ \\
\hline RB3 & $\begin{array}{l}\text { Siliceous } \\
\text { clay and } \\
\text { fine-grained } \\
\text { sandstone }\end{array}$ & $\begin{array}{l}\text { Transit- } \\
\text { ional }\end{array}$ & $\begin{array}{l}\text { Transit- } \\
\text { ional }\end{array}$ & $\begin{array}{l}\text { Light grey } \\
\text { and } \\
\text { purple }\end{array}$ & $2.7-3$ & 1.3 & Persistent & Planer & Unobserved & $\begin{array}{l}\text { Alternations of } \\
\text { siliceous claystone } \\
\text { and fine-grained } \\
\text { sandstone layers } \\
1.3 \mathrm{~cm} \text { thick }\end{array}$ & $\begin{array}{l}\text { Quiet, shallow } \\
\text { marine. Seaward } \\
\text { of RB2 }\end{array}$ \\
\hline RB2 & $\begin{array}{l}\text { Sandstone } \\
\text { with minor } \\
\text { shale }\end{array}$ & $\begin{array}{l}\text { Transit- } \\
\text { ional }\end{array}$ & $\begin{array}{l}\text { Transit- } \\
\text { ional }\end{array}$ & $\begin{array}{l}\text { Greenish } \\
\text { and grey }\end{array}$ & 9 & $2-70$ & Persistent & $\begin{array}{l}\text { Planer to } \\
\text { slightly } \\
\text { irregular }\end{array}$ & $\begin{array}{l}\text { Horizontal } \\
\text { lamination } \\
\text { where } \\
\text { observable }\end{array}$ & $\begin{array}{l}\text { Symmetrical } \\
\text { and } \\
\text { asymmetrical } \\
\text { ripple marks }\end{array}$ & $\begin{array}{l}\text { Shallow } \\
\text { marine }\end{array}$ \\
\hline RB1 & Conglomerate & $\begin{array}{l}\text { Discon- } \\
\text { formable }\end{array}$ & $\begin{array}{l}\text { Transit- } \\
\text { ional }\end{array}$ & $\begin{array}{l}\text { Maroon } \\
\text { and } \\
\text { white }\end{array}$ & $2 \cdot 25$ & $20 \cdot 150$ & Lenticular & $\begin{array}{l}\text { Curved } \\
\text { erosive. } \\
\text { sharp }\end{array}$ & $\begin{array}{l}\text { Massive to } \\
\text { poor normal } \\
\text { or inverse } \\
\text { grading }\end{array}$ & $\begin{array}{l}\text { Textural maturity } \\
\text { variable. Channels } \\
3 \text { to more than } \\
20 \mathrm{~m} \text { wide }\end{array}$ & $\begin{array}{l}\text { Alluvial fans with } \\
\text { braid channels in } \\
\text { a nearshore } \\
\text { setting }\end{array}$ \\
\hline
\end{tabular}


glomerates typify this lithofacies (Fig. 3a). Bed thickness ranges from $20 \mathrm{~cm}$ to $1.5 \mathrm{~m}$ and the beds are generally lenticular, pinching out laterally over a distance of $3 \mathrm{~m}$ to more than $20 \mathrm{~m}$, and possess scoured or erosive bases. Clasts are commonly 2-7 $\mathrm{cm}$ in diameter but vary from less than $1 \mathrm{~cm}$ to up to $30 \mathrm{~cm}$. Sorting is generally poor. In most units the clasts are rounded to subrounded and are composed of reddish coloured quartzite, white quartz, red and green jasper and felsic volcanics. McCutcheon et al. (1982) noted that several of the volcanic clasts possessed pre-depositional deformation fabrics; however, we were unable to confirm this observation. Petrographic analysis performed by Tanoli (1987), however, has revealed such fabrics in several quartzite clasts. The matrix is typically maroon coloured sandstone. Rarely, crudely developed normal and inverse grading is observed in some units (Fig. 3b) and, though beds are typically massive, a single bed was observed to exhibit faintly developed cross-stratification.

The uppermost $2 \mathrm{~m}$ consists of white, extremely mature, pebbly sandstone-conglomerate layers. Crude inverse grading was observed in one of these layers and in another, faintly developed low angle cross-stratification. The lateral continuity of these latter strata was not determined due to lack of exposure. The exposed thickness of this facies is more than $25 \mathrm{~m}$ at Hanford Brook and 3-4 $\mathrm{m}$ at Mystery Lake.

\section{Interpretation}

The generally massive and amalgamated nature of the beds, their scoured or channelized erosive bases, as also suggested by the lenticular bedding geometry, and the absence of intervening shale or sandstone together suggest deposition from ephemeral streams, particularly in association with alluvial fans (Nemec and Steel, 1984). The textural immaturity, grading and rare presence of cross-stratification possibly suggest deposition in the distal portions of such alluvial fans (cf. Bluck, 1967; Gloppen and Steel, 1981; Rust and Koster, 1984). Close association of facies RB1 with overlying marine units may suggest deposition in a coastal setting (cf. Daily et al., 1980; Gjelberg and Steel, 1983).

Facies RB 1 is therefore envisaged as having formed in braid channels associated with distal portions of an alluvial fan, possibly in a coastal setting. The uppermost $2 \mathrm{~m}$ of more mature conglomerates and pebbly sandstones may represent either beach lag deposits (cf. Bourgeois and Leithold, 1984) or wave-reworked fanglomerates, formed in response to the early Cambrian marine transgression. Because these latter strata are underlain by fanglomerates possibly formed in a coastal setting and overlain by shallow marine sandstones of facies RB2, it is tempting to favour the latter interpretation.
Facies RB2 - Rippled and non-rippled sandstone

Location: Hanford Brook and Mystery Lake area (Fig. 1).

\section{Description}

At Hanford Brook, this lithof acies consists of $9 \mathrm{~m}$ of $2-70 \mathrm{~cm}$ (average $25 \mathrm{~cm}$ ), thick beds of medium-grained, greenish and grey micaceous sandstone. Most beds are separated by shale layers a few millimetres to a few centimetres thick, but rarely they are amalgamated. The basal sandstone bed is $70 \mathrm{~cm}$ thick and at its base possesses a very thin veneer of small quartz pebbles, up to $1.5 \mathrm{~cm}$ in diameter, and flattened chamositic nodules, up to 2.5 $\mathrm{cm}$ long. The top of this bed contains a thin granule lag composed of quartz grains and chamositic nodules which are up to $3.5 \mathrm{~cm}$ long (Fig. 4). Within the lower half of the lithofacies, an $8 \mathrm{~cm}$ thick bed consists of horizontally stratified quartz pebble conglomerate, the quartz pebbles averaging $0.5 \mathrm{~cm}$ (up to $1 \mathrm{~cm}$ ) in diameter. Most beds constituting the central portion of the facies are $2-10 \mathrm{~cm}$ thick and possess small scale $(\lambda=5.5 \mathrm{~cm})$ symmetrical and asymmetrical wave-formed ripples on their upper surfaces. Internally they are parallel- or cross-laminated and several beds contain glauconies (sensu Odin and Letolle, 1980). The upper sandstone beds possess a relatively high mud content and, as a result, are partially cleaved so that internal structures are difficult to observe.

Near Mystery Lake the facies consists of $8.8 \mathrm{~m}$ of $25-80 \mathrm{~cm}$ thick, medium-grained, maroon sandstone beds. In the middle and upper parts, 3-7 cm thick siliceous claystone layers, which generally pinch out laterally over a few metres, constitute either the base or top of several of these sandstone beds. Internal organization, where visible, is predominantly horizontal lamination. The basal bed, which is $80 \mathrm{~cm}$ thick, possesses several maroon, elongate claystone/siltstone fragments up to $15 \mathrm{~cm}$ in length. Microscopically, sandstones of facies RB2 are compositionally and texturally more mature in their lower portions, consisting of well-rounded quartz grains with minor amounts of feldspar and muscovite. Authigenic quartz overgrowth is common. Cement is dominantly quartz with minor amounts of carbonate, and several grains are coated with hematite.

\section{Interpretation}

At Hanford Brook, evidence of wave activity in the form of symmetrical and asymmetrical ripples, and of current activity in the form of upper surface granule lags (cf. Levell, 1980), suggest deposition in shallow water conditions. The presence of authigenic chamosite and glauconies suggests a marine environ-

Fig. 3. Facies RB1 of the Ratcliffe Brook Formation. (a) Massive, matrix-supported conglomerate with rounded, essentially quartzite, clasts. Location, Hanford Brook; lens hood is $5.5 \mathrm{~cm}$ in diameter. (b) Lenticular layers of matrix-supported conglomerates exhibiting poorly-developed inverse to normal grading. Location, Porter Road; hammer is $32 \mathrm{~cm}$ in length. 

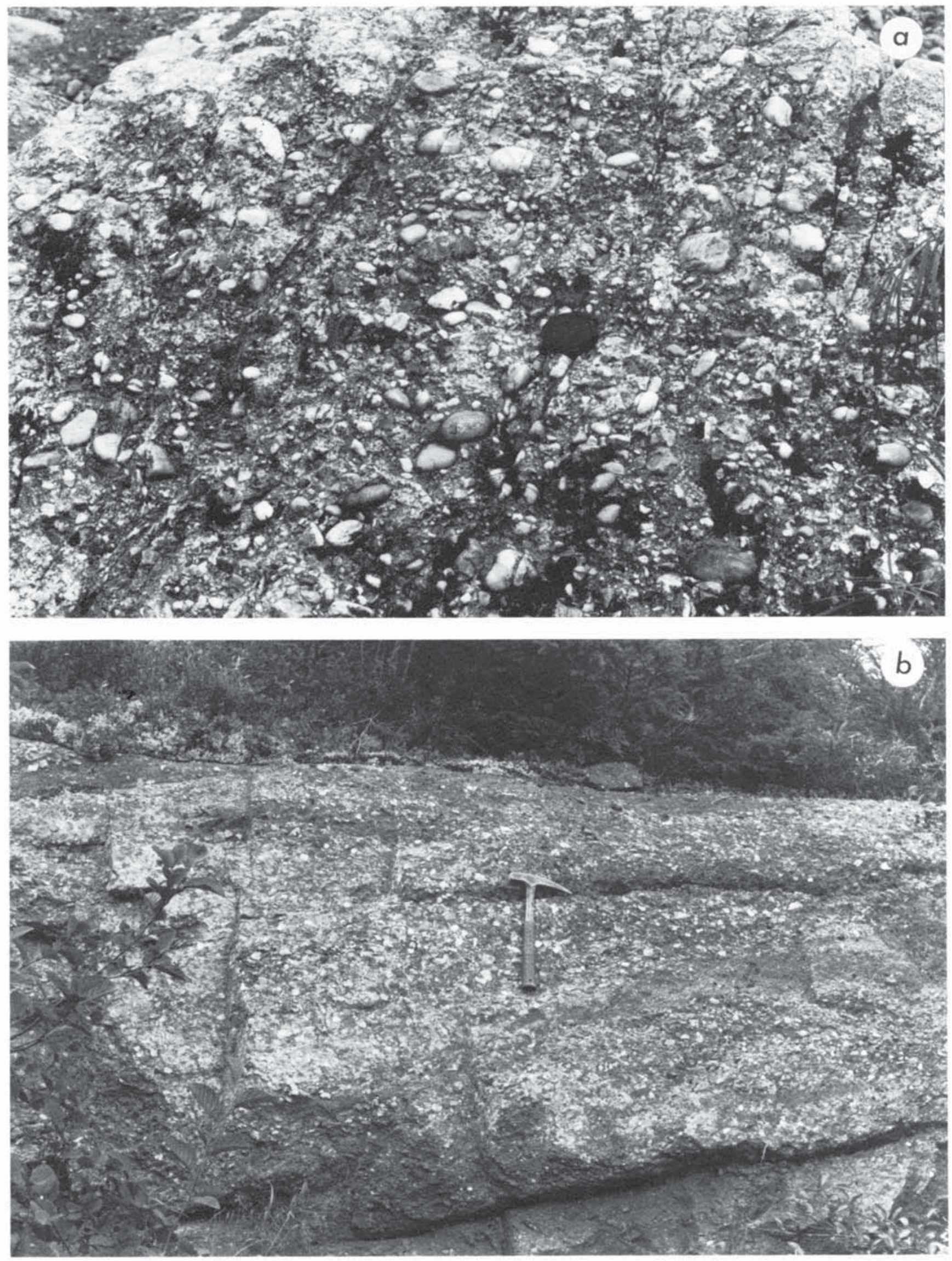


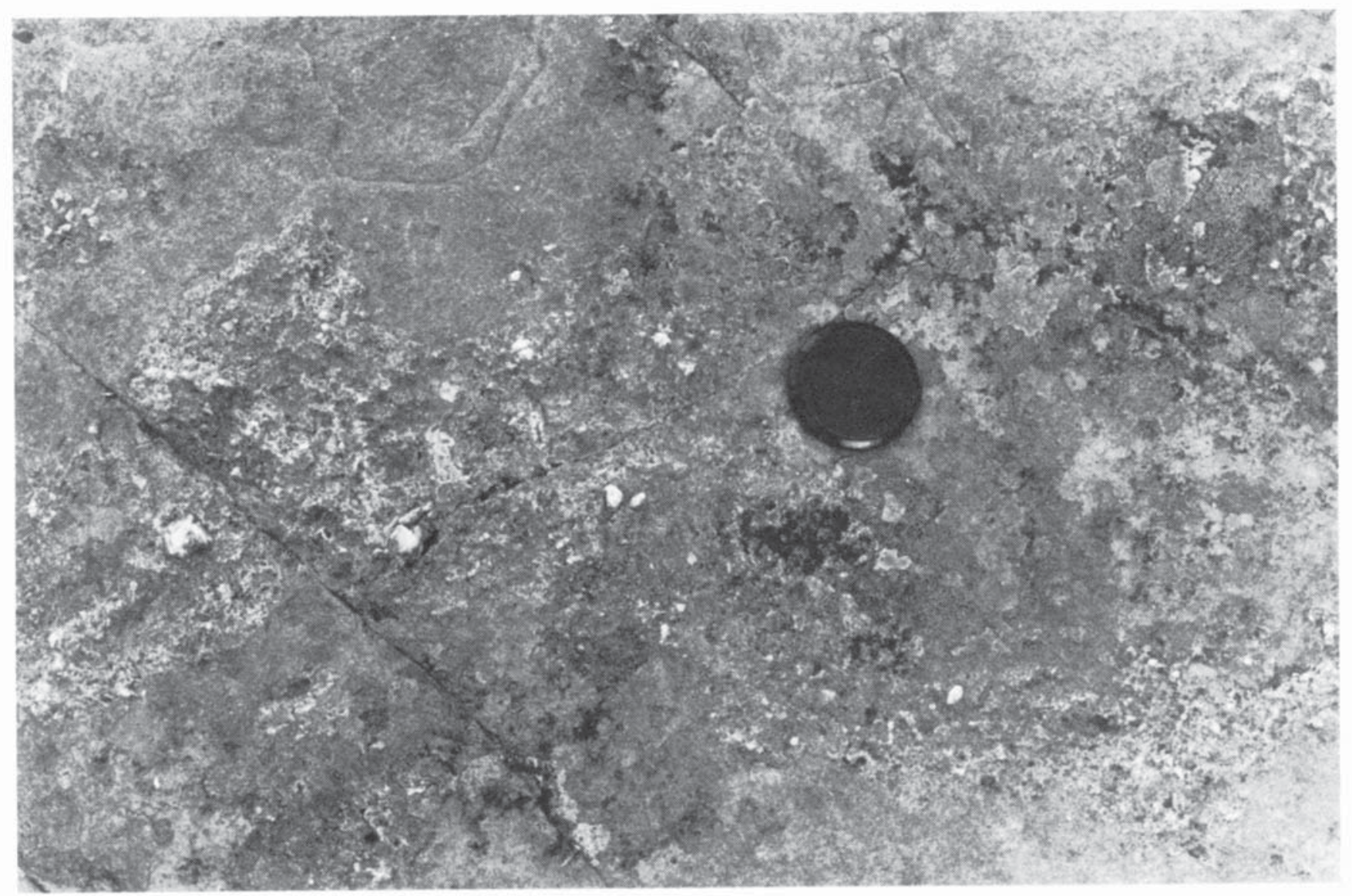

Fig. 4. Granule lag on the upper surface of a sandstone layer of facies RB2. Location, Hanford Brook; lens hood is $5.5 \mathrm{~cm}$ in diameter.

ment (Van Houten and Purucker, 1984) subject to relatively slow depositional rates (Odin and Matter, 1981; Ireland et al., 1983). The basal pebbly sandstone bed was possibly formed as a result of reworking, during relatively high energy conditions, of coarse sediments supplied to the shoreline by streams or by longshore currents (cf. Leithold and Bourgeois, 1984). The nature of the ripples, the absence of lenticular beds and channeling, and the relatively high frequency of mud both within and between the sandstone beds in the remainder of the sequence, together suggest deposition in a generally low energy shelf environment.

At Mystery Lake, the lower half of facies RB2, which is thicker bedded and more mature than the upper half, is also interpreted to have been deposited in a very shallow marine nearshore environment. The horizontal laminae probably reflect the role of upper flow regime processes, as previously interpreted from other nearshore environments (e.g., Carter, 1978; Reinson, 1984). General fining upward of the facies along with thinning of beds and increase in frequency of the siliceous claystone layers in the upper portion indicate more subdued and probably seaward environments of deposition than the underlying beds. The aligned maroon siltstone/claystone fragments in the basal bed may have been the result of storm activity.

\section{Facies RB3 - Layered siliceous claystone and fine-grained} sandstone

Location: Near Mystery Lake behind the Skyline Apartment Building (Fig. 1).

\section{Description}

This facies is composed of alternating, $1-3 \mathrm{~cm}$ thick, light grey and purple siliceous claystone and dark maroon, finegrained sandstone layers (Fig. 5a). These strata are laterally persistent, at least on outcrop scale, and no internal structures were observed in outcrop or polished hand specimens. Thin section analysis, however, reveals abrupt and erosive lower contacts and gradational upper contacts of the sandy layers with respect to the siliceous layers (Fig. 5b). The facies is only 2.7-3 $m$ thick and is underlain and overlain, respectively, by facies RB2 and RB5. The facies is only locally developed and has been recognized only at Mystery Lake.

Fig. 5. (a) Alternating siliceous claystone and fine-grained sandstone layers of facies RB3. Location, Mystery Lake area behind the Skyline Apartment Building; hammer is $32 \mathrm{~cm}$ in length. (b) Photomicrograph of erosional contact between a medium-grained sandstone (upper) and siliceous claystone layer (lower) from facies RB3. Location, as above; $x 35$. (c) Photomicrograph of chamositic nodules (arrowed) in a medium-grained sandstone layer of facies RB4. Location, Hanford Brook; $x 20$. 


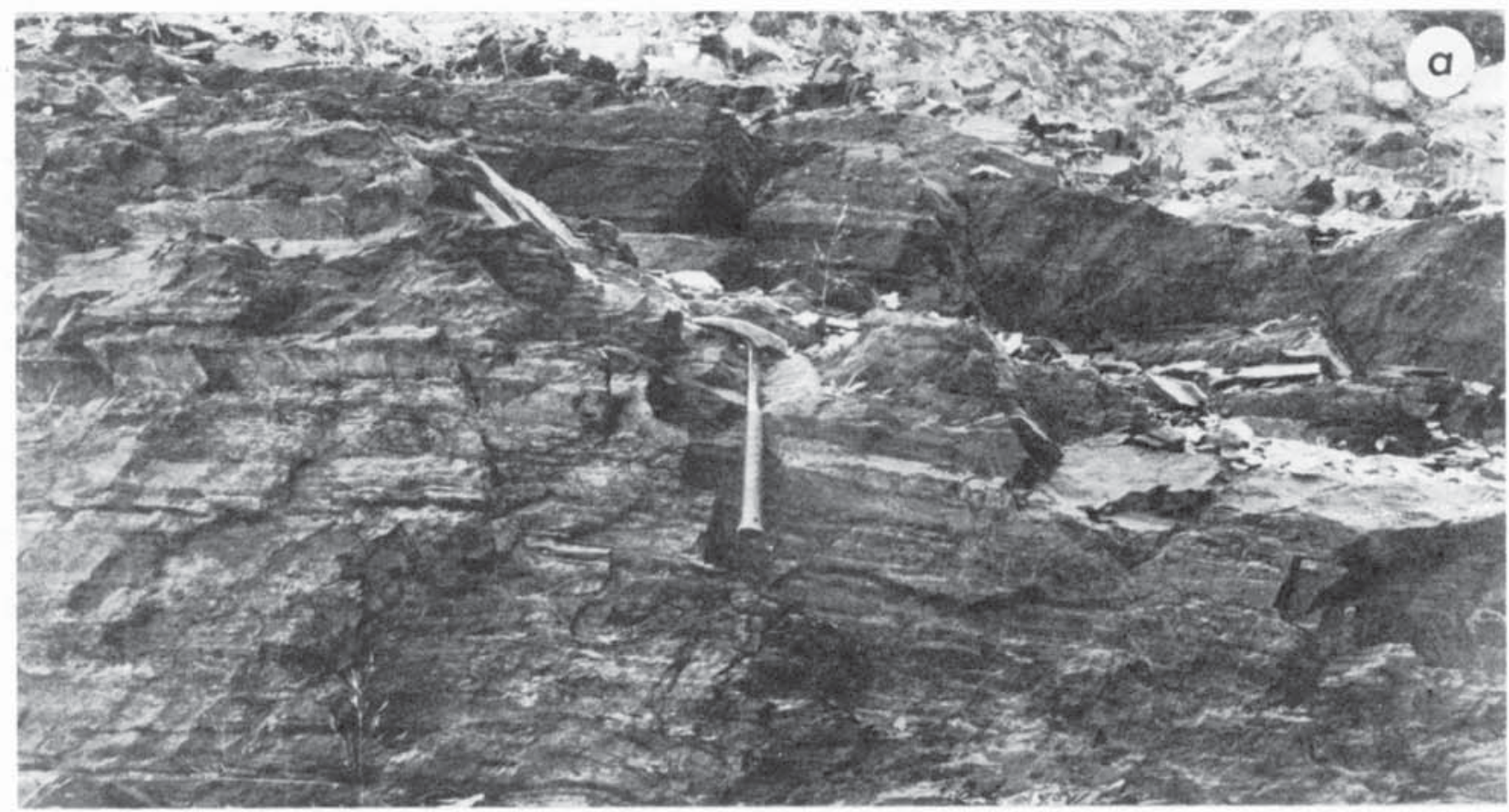

(5)

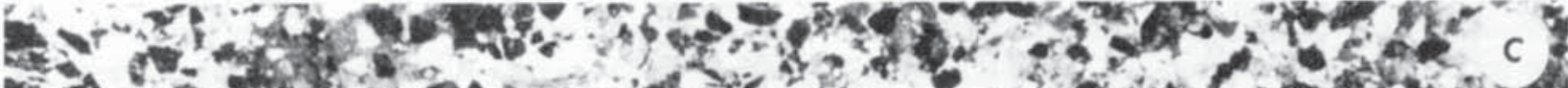

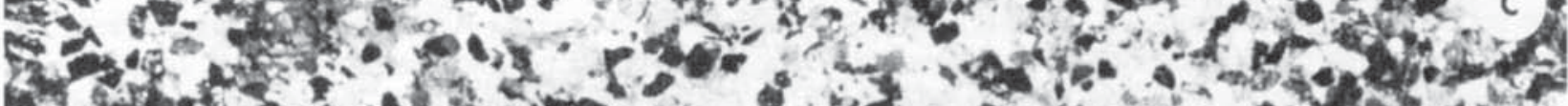

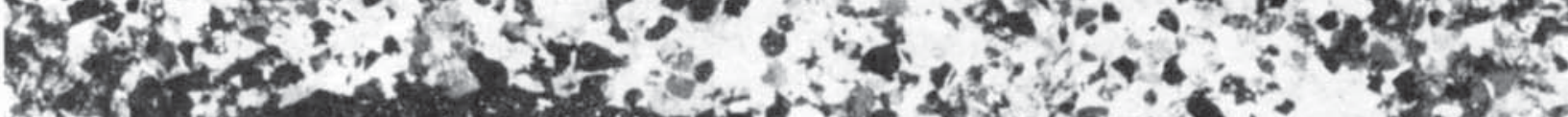

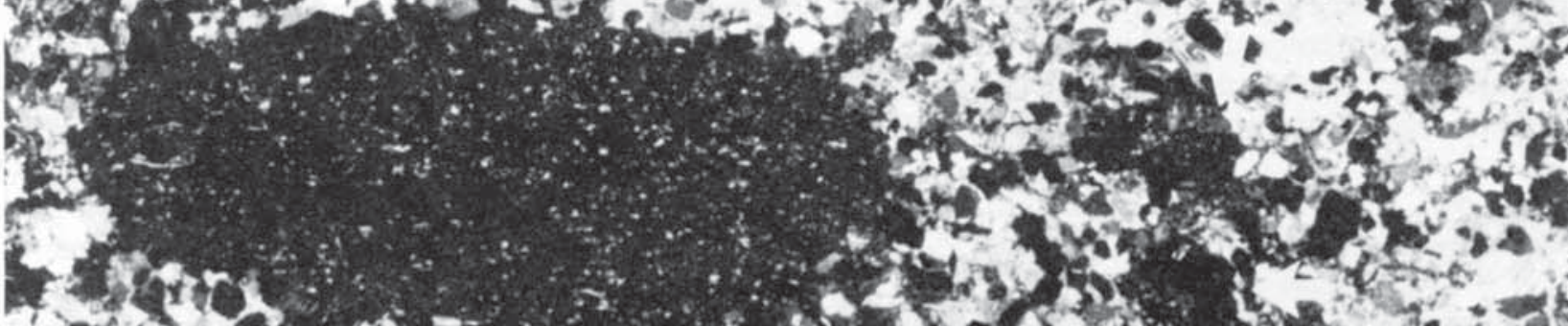

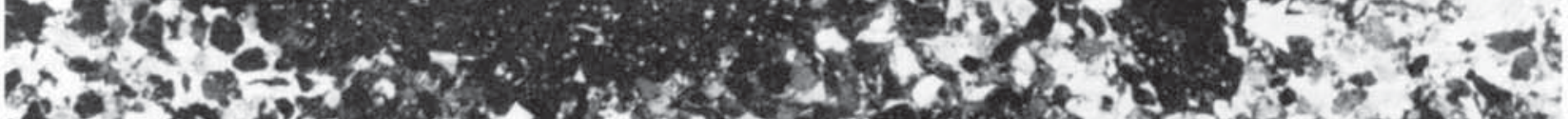

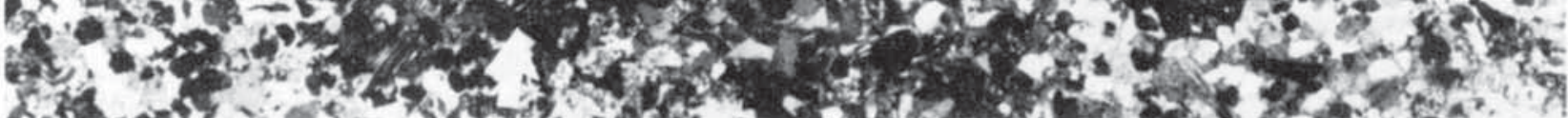




\section{Interpretation}

The absence of diagnostic criteria makes interpretation of facies RB3 extremely difficult. The varve-like layering has, however, been previously described from generally quiet water marine environments (Wilson, 1958). The relatively fine grain size and the absence of evidence of wave and current activity suggest generally quiet water conditions. Additionally, the facies is sandwiched between facies RB2 and RB5, both of which are marine in origin. Tentatively, therefore, we conclude that facies RB3 was deposited in a relatively quiet shallow marine environment seaward of facies RB2. The siliceous claystone layers are suggested to have been deposited during quiet intervals. Whether the silica content of these clays was inherited directly from the source rocks or resulted from high silica concentration of ambient waters is not clear. Interbedded sandstone layers were probably introduced during periodically developed higher energy conditions such as increased wave, storm or tidal activity, or even combinations of these processes, as suggested by their erosive bases and gradational tops (cf. Aigner, 1985).

\section{Facies RB4 - Greenish-grey chamositic sandstone and siltstone}

Location: Hanford Brook (see Fig. 2).

\section{Description}

The lower $3 \mathrm{~m}$ of this facies comprises 30 to $50 \mathrm{~cm}$ thick layers of greenish-grey, fine-grained, massive or parallel-laminated, amalgamated, micaceous sandstones containing scattered chamosite nodules (recognized by X-ray diffraction and Scanning Electron Microprobe analysis), some of which are aligned parallel to stratification (Fig. 5c). The cement in these sandstones is predominantly carbonate. The tops of several of these sandstone beds are patchily capped with a thin veneer of chamosite pebbles and quartz granules. The overlying 6-7 m consists of amalgamated, massive or parallel-laminated siltstone layers where individual bed thickness is difficult to estimate. Rare examples of cross-laminated sets occur within several of the siltstones. The beds in the upper portion of the lithofacies, which is approximately $5 \mathrm{~m}$ thick, comprise fine-grained siltstone and shale with rare fine-grained sandstone lenses. Individual beds are difficult to recognize and generally appear massive but $1-3 \mathrm{~cm}$ thick, maroon and light coloured horizontal laminae are visible locally, particularly in relatively coarser grained beds. This upper portion of the lithofacies is gradational with the lower portion of subfacies RB5a.

\section{Interpretation}

As with facies RB3, because of poor exposure and the absence of specific environmental indicators, interpretation of facies RB4 must be regarded as tentative. Evidence of current activity is certainly present in the form of cross-laminated sets, chamosite and quartz granule lags (cf. Levell, 1980), and of sandstone lenses and layers in the shaly and silty beds (cf. Allen, 1970; Brenchley and Pickerill, 1980). No evidence of wave activity is, however, preserved in this facies. The strata, which are sandwiched between marine strata of facies RB2 and RB5, were deposited in shallow water marine conditions as indicated by the presence of in situ chamosite nodules, which are typically formed in shallow marine conditions (see Porrenga, 1967; Van Houten and Purucker, 1984). The generally fine-grained nature of the strata of this facies, the absence of evidence of wave activity and the presence of in situ chamosite nodules, suggest their formation seaward of the underlying facies RB2, probably as a result of continued transgression. The stratigraphic position of this lithofacies at Hanford Brook, where it occurs between facies RB2 and RB5 (Fig. 2) parallels that of facies RB3 in the Mystery Lake area. We tentatively suggest that facies RB3 and RB4 are lateral equivalents, both formed seaward of facies RB2 but within different, and admittedly enigmatic, environmental regimes.

Facies RB5 - Maroon, thick-bedded, medium- to coarsegrained sandstone and conglomerate

This facies, strata of which present a record of progradation within the sequence, is divided into two subfacies, herein termed RB5a and RB5b, on the basis of lithology and relative stratigraphic position within the sequence. Subfacies RB5a underlies RB5b.

\section{Subfacies RB5a}

Location: At Hanford Brook and near Mystery Lake behind the Skyline Apartment Building (Fig. 1).

\section{Description}

This lithofacies gradationally overlies facies RB4 at Hanford Brook and facies RB3 near Mystery Lake. At Hanford Brook it consists of dominantly maroon, greenish-grey, mediumto coarse-grained quartzose and micaceous sandstones. These exhibit sharp bases and tops and are typically laterally continuous, more rarely lenticular. Bases may be planar, irregular, erosive or non-erosive. Ripple marks, synaeresis cracks and trace fossils may be present but are not common. The trace fossils (Helminthoidichnites tenuis Fitch, Palaeophycus tubularis Hall, Psammichnites gigas Matthew, Subphyllochorda? isp., Taphrhelminthoida dailyi Hofmann and Patel and Taphrhelminthopsis cf. $T$. circularis Crimes et al.) occur near the base of the subfacies in Unit II, localities 1-3, of Hofmann and Patel (1989). Bed thickness ranges from $20 \mathrm{~cm}$ to more than a meter, although it is typically $50-70 \mathrm{~cm}$. Internally, most beds exhibit up to $5 \mathrm{~mm}$ thick, typically thinner, horizontal laminae. These may be recognized by alternating darker and lighter colour (Fig. 6a), slightly different grain size variation or, particularly in the upper portion of the subfacies, by the presence of common quartz granules arranged in distinct but thin layers (Fig. 7b). Several beds exhibit unidirectional or bidirectional cross-laminated sets, 4-24 cm thick, commonly $5-15 \mathrm{~cm}$ thick, and internal erosion 
surfaces (Fig. 7a). Rarely, such sets are overlain by horizontal laminae. A single erosively-based, and exceptionally coarsegrained, normally graded bed at Hanford Brook was observed to consist of unidirectional cross-laminae throughout (Fig. 6b). This bed possesses rounded siltstone or shale clasts, up to $22 \mathrm{~cm}$ in length, each with its long axis parallel to the dip of the laminae. The sandstone units are arranged into a broadly coarseningupward sequence which is further continued within subfacies RB5b (Fig. 2).

Exposure of this subfacies at Hanford Brook, which is mostly within the stream bed and can be observed only at very low water levels, precludes estimates of the amount of shale present. Overlying the erosive based sandstone bed noted above (Fig. 6b) is an $80 \mathrm{~cm}$ thick, maroon, micaceous shale, but this is the only example where shale was actually observed. However, patchy exposures along the banks of the brook confirm its general absence and the presence, instead, of amalgamated sandstone beds (Fig. 6a). Total thickness of this subfacies at Hanford Brook is approximately $63 \mathrm{~m}$.

Petrographic analysis suggests that in general both the grain size and textural and mineralogical maturity of these sandstones increase upward in the subfacies. The lowermost sandstones are composed of subrounded quartz with small proportions of feldspar, rock fragments, micas and glauconies enclosed within a quartz overgrowth and calcite matrix. The uppermost sandstones are composed of coarse, well-rounded quartz grains with small proportions of feldspar, micas and rock fragments which are also well-rounded. Quartz overgrowth is very common as a siliceous cement.

Near Mystery Lake the subfacies consists of $22 \mathrm{~m}$ of 50-160 $\mathrm{cm}$ thick, laterally continuous, maroon, medium-grained, amalgamated sandstone beds. Several beds appear massive but in many, particularly those possessing quartz granules, the presence of horizontal lamination can be discerned upon close examination. Rare, $1-4 \mathrm{~cm}$ thick, lenticular siliceous claystone layers are also observed at the base or top of several sandstone beds.

\section{Subfacies RB5b}

\section{Location: Hanford Brook}

\section{Description}

This lithofacies comprises a broadly upward-coarsening sequence of $18 \mathrm{~m}$ of amalgamated maroon and white, purplish to reddish-brown, pebbly, quartzose (quartz and quartzite) sandstone and pebble-cobble conglomerate beds, each typically between $40-70 \mathrm{~cm}$ in thickness. Bedding contacts are only rarely observed but where present are sharp and erosive; we assume unexposed contacts to exhibit a similar geometry. Both normal and inverse grading are present within several beds, whereas pebble-cobble conglomerate lags are observed at the top of others, particularly in the upper portion of the facies. Bipolar cross-stratification, with individual laminae up to $2-3 \mathrm{~cm}$ in thickness, are present within several beds (Fig. 8a). The lateral continuity of these beds outside the brook cannot be evaluated due to heavy vegetation cover, but no interbedded shale units were observed. Hofmann and Patel (1989) have recorded Monocraterion from this subfacies (their Unit III, locality 4 - see Hofmann and Patel, 1989, fig. 1).

\section{Interpretation of Facies RB5}

Subfacies RB5a is interpreted to have been deposited in a high energy nearshore shallow marine shoreface-foreshore environment. Textural and compositional maturity, relatively thick horizontally laminated beds with generally uniform thickness laterally, and the insignificant proportion of shale together suggest deposition in high energy conditions (cf. Clifton et al., 1971; Clifton, 1973). The presence of glauconies and definitively marine trace fossils (Hofmann and Patel, 1989) are indicative of marine conditions. Alternating light and dark laminae are characteristic of foreshore to upper shoreface environments (Clifton et al., 1971; Cotter, 1983), as are laminae formed by coarser grained pebble or granule layers (Howard and Reineck, 1981; McGubbin, 1982). Lenticular beds in such environments, produced as a result of either migration of longshore troughs or deposition in rip-current channels or tidal reworking, have been recorded by McCubbin (1982) and Leithold and Bourgeois (1984). Erosively based and normally graded units are perhaps storm-related and the rare shales are indicative of periods of extended and reduced wave and current activity. The siliceous claystone layers within this subfacies also probably formed in quiet periods from waters with a high silica concentration. Hofmann and Patel (1989) also suggested a shallow water deltaic?, lagoonal or tidal flat depositional environment for subfacies RB5a as defined herein, but without giving additional details.

Subfacies RB5bconstitutes the upper portion of the coarsening-upward sequence initiated at the base of subfacies RB5a. The coarse grain size, the presence of conglomerate lags, erosive bases, normal and inverse grading and the marine trace fossil Monocraterion suggest rapidly deposited units in a high energy nearshore marine environment landward of subfacies RB5a. Poor exposure of the strata prevents evaluation of the lateral continuity of the units, though we regard them as possibly channelized. These observations, together with the fact that the subfacies is underlain by strata interpreted as having been deposited in a shallow marine shoreface-foreshore environment (subfacies RB5a) and overlain by strata deposited in lagoonal conditions (facies RB6), suggest deposition in distributary channels on the delta plain of a prograding delta complex (cf. McBride $e t$ al., 1975; Elliott, 1986). The paucity of shale units may suggest a possible fan-delta type setting (cf. Westcott and Ethridge, 1980). Bidirectional cross-stratification of several units suggests tidal reworking within the distributary channels (cf. Hayes, 1979).

Facies RB6 - Greenish and maroon shale, siltstone, sandstone and volcanogenic sandstone

Location: At Hanford Brook, and Somerset Street and Lancaster Street in the city of Saint John, and at Campbell Road and Catons Island in the Long Reach (Fig. 1). 

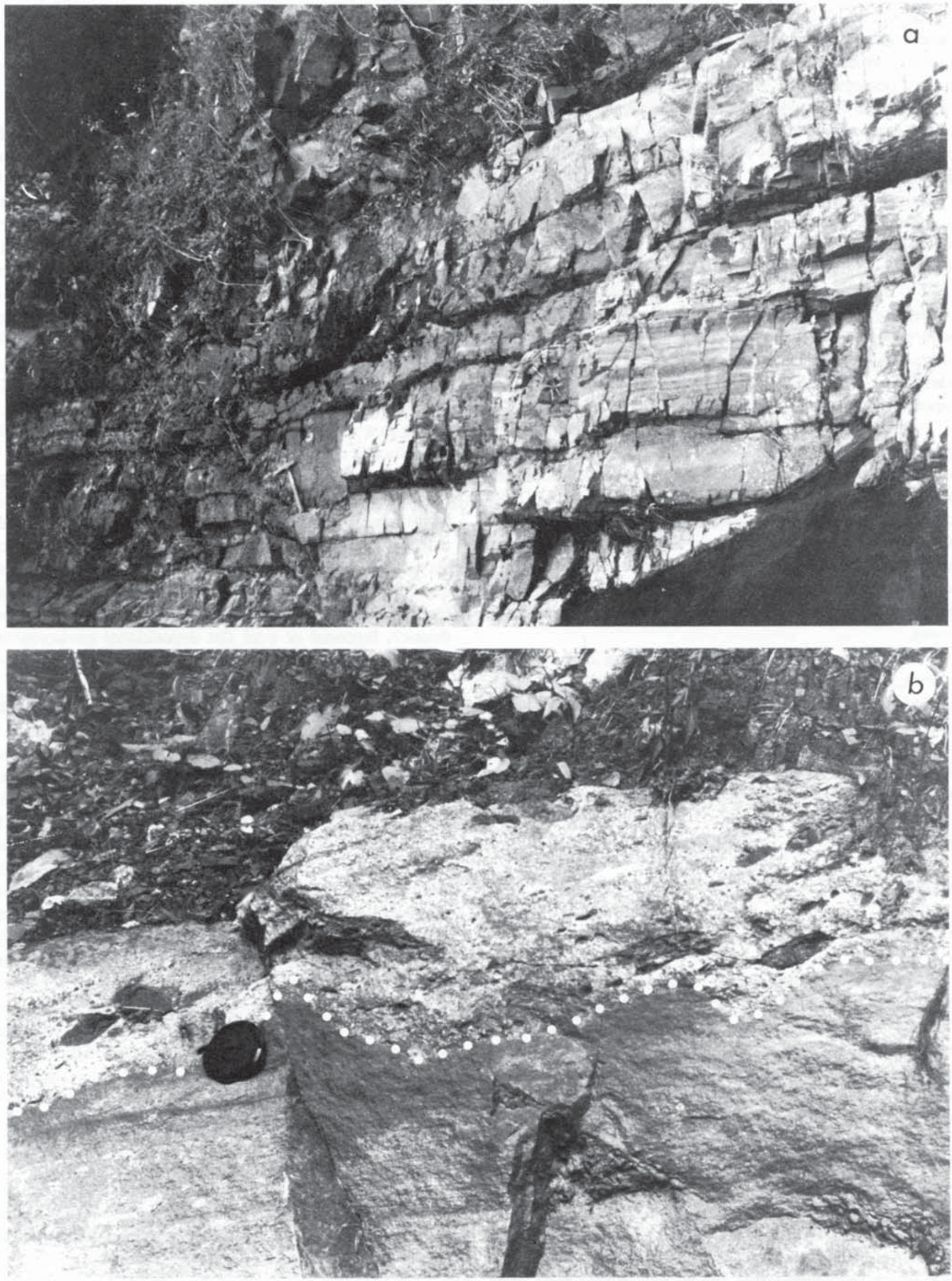


\section{Description}

This facies, with respect to both its thickness and lithology is by far the most variable areally. At Hanford Brook it constitutes the thickest facies of the Ratcliffe Brook Formation (ca. 110 m - see Fig. 2) and corresponds to Unit IV of Hofmann and Patel (1989) and unit 6 of McCutcheon (1987). There, most units are composed of interbedded shale and siltstone or very fine-grained sandstone of greenish-grey, purple and greenish-maroon colour. Individual beds are typically $30-50 \mathrm{~cm}$, but range from $1-90 \mathrm{~cm}$, in thickness. Matthew (1889) recorded Volborthella tenuis Schmidt, Obolus(?) major Matthew and, Platysolenites antiquissimus Eichwald (the former two recently synonymized with "Allatheca" degeeri (Holm) by Landing et al. (1989)), and Walcott (1900) reported additional marine body fossils (including Hyolithes, Coleoloides and Iphidea) from approximately $10 \mathrm{~m}$ above the base of this facies at Hanford Brook. We haveobserved diffuse and generally non-diagnostic bioturbation structures in several beds. As previously noted, the presence of body fossils remains to be confirmed.

The siltstone and sandstone beds appear structureless (Fig. $8 \mathrm{~b})$, presumably a function of weathering, or are parallel-laminated. Several layers consist of alternating darker and lighter coloured horizontal laminae. The base of several layers consist of greenish, maroon, hard, siliceous claystone up to $15 \mathrm{~cm}$ in thickness. Finer grained layers commonly possess discontinuous lenses of sandstone which are typically internally current-ripple and possibly wave-ripple cross-laminated. Amalgamation of sandstone layers is relatively common, particularly toward the upper exposed portion of the facies. Randomly selected samples throughout the facies reveal the presence of glauconies (Odin and Letolle, 1980) in all the sandstones. In the upper exposed part of the facies, beds are amalgamated and are massive, generally more fine-grained and partially cleaved.

The same facies at Somerset Street in Saint John is represented by approximately $28 \mathrm{~m}$ of dark grey or black, $1-3 \mathrm{~cm}$ thick interbeds of shale and grey, medium-grained, massive, or horizontally to wavy laminated sandstone (Fig. 8c) with rare chert layers. In the upper portion a $30 \mathrm{~cm}$ thick volcanic ash bed is also present. The uppermost $1.5 \mathrm{~m}$ consists of grey, hard, fine- to medium-grained sandstone beds which are transitional with overlying strata of the Glen Falls Formation.

At Lancaster Street the facies consists of approximately 27 $m$ of $25-50 \mathrm{~cm}$ thick, grey and red, fine-grained sandstone beds which exhibit poorly developed parallel-lamination and rare small scale cross-lamination. The grey sandstone beds are well sorted and texturally more mature than the red sandstones, which are poorly sorted and contain a high proportion of angular quartz grains.
At Campbell Road in the Long Reach the facies is represented by dark grey, thinly bedded $(1-3 \mathrm{~cm})$ cleaved siltstones which are in direct and sharply disconformable contact with upper Precambrian conglomerates. Tanoli et al. (1985) have discussed the criteria enabling distinction of these upper Precambrian conglomerates from similar lithologies within the Ratcliffe Brook Formation. Interbedded with these siltstones are several beds of grey, typically massive, rarely parallel-laminated, coarseand medium-grained sandstone, and pebbly sandstone, the thickness of which ranges up to $40 \mathrm{~cm}$. Two of these beds are normally graded, their bases containing rounded, $0.5-1.5 \mathrm{~cm}$ diameter quartz and volcanic pebbles. No other physical features were observed in them.

At Catons Island the lower portion of the facies consists dominantly of interbeds of fine-grained, $20-30 \mathrm{~cm}$ thick, greenish-grey and maroon siltstones and mudstones. Internally, most siltstone beds consist of alternate wavy, rippled, flasered and horizontal layers, more rarely lenses, of $0.2-8 \mathrm{~cm}$ thick greenish siltstone and maroon mudstone (Fig. 9a). Interbedded with these fine-grained strata are $10-70 \mathrm{~cm}$ thick, medium- to coarsegrained red volcanogenic sandstone beds which possess sharp lower and upper bedding planes. They appear massive and are laterally continuous, at least on outcrop scale (several meters). The upper portion of the sequence at Catons Island consists of red, coarse-grained volcanogenic conglomerate and sandstone, grey medium-grained sandstone and grey shale, and red siltstone and silty shale or greenish-grey shale arranged systematically into three $13 \mathrm{~m}$ thick fining- and thinning-upward sequences. In a single example, the fining-upward sequence is initiated by a $0.75 \mathrm{~m}$ thick conglomerate bed which is inversely and then normally graded (Fig. 9b). The reddish pebbles and cobbles are up to $14 \mathrm{~cm}$ in diameter, subangular to subrounded and are rhyolitic in composition. The top of this conglomerate bed consists of $1.5-2 \mathrm{~cm}$ diameter rounded quartz and jasper pebbles enclosed in a dominantly siliceous matrix.

Microscopic analysis indicates that the volcanogenic sandstones in the lower portion of the facies at Catons Island are relatively more mature and better sorted than those of the finingupward sequences in the upper portion. The former consist of angular to subrounded quartz grains with relatively more rounded shale or siltstone rock fragments. In the latter the majority of grains are subangular (although some are rounded, probably due to their larger size), and sorting is poor. The grey and maroon medium-grained sandstones are relatively more mature and better sorted, and consist of subrounded to rounded grains of quartz, feldspar and red shale or siltstone.

Fig. 6. (a) Horizontally laminated, amalgamated sandstone layers of facies RB5a. Location, Hanford Brook; hammer is $32 \mathrm{~cm}$ in length. (b) Erosional contact (dotted) between a horizontally laminated lower sandstone layer and an overlying cross-stratified layer with mudstone clast long-axes paralleling dip of foresets (arrowed) from facies RB5a. Location, Hanford Brook; lens hood is $5.5 \mathrm{~cm}$ in diameter. 

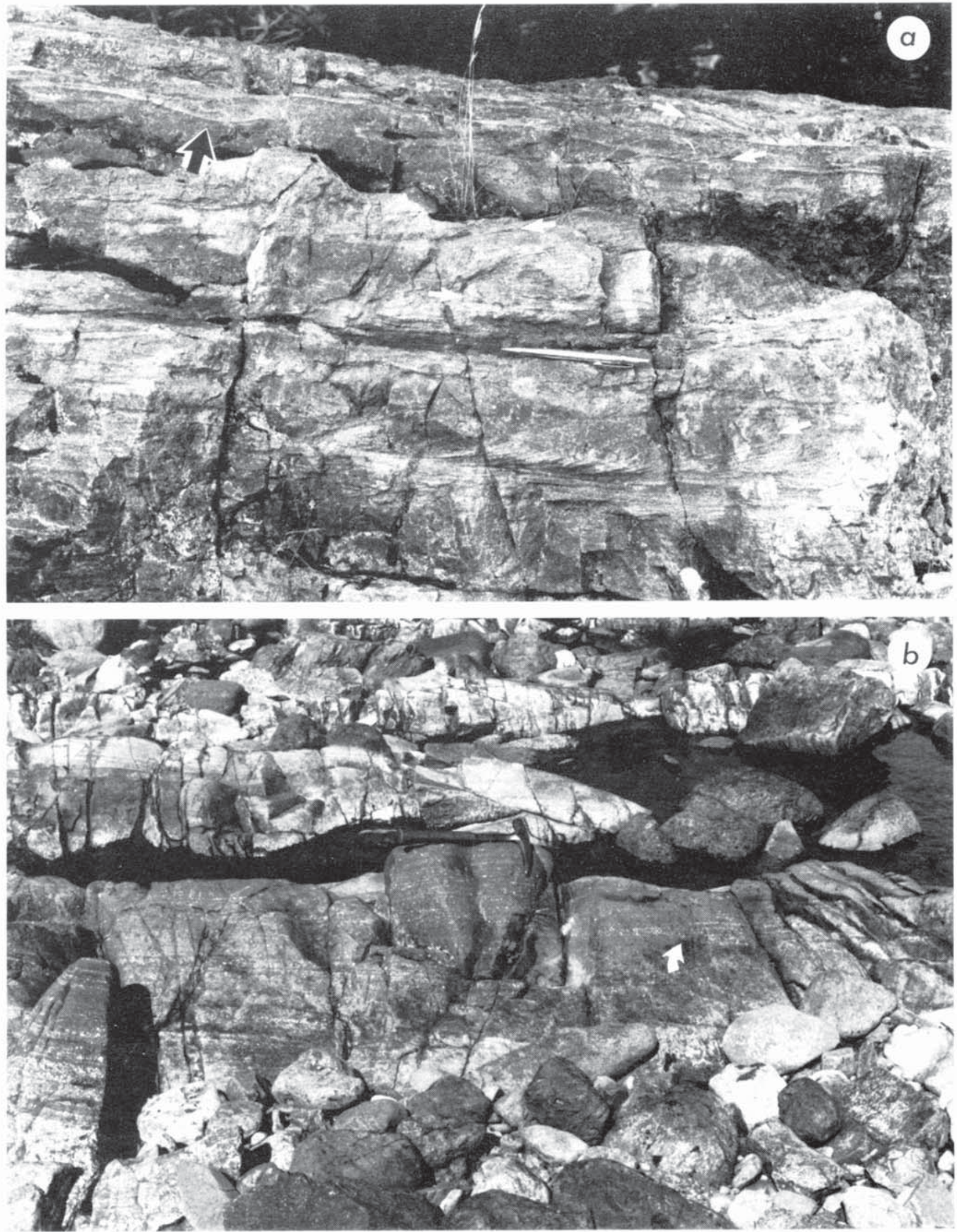


\section{Interpretation}

Although the lithofacies exhibits considerable variation in its temporal and spatial development of lithology, textural maturity, composition and internal features, we believe that such variations resulted from derivation of material from different source areas and its introduction by various mechanisms into what we interpret herein as a single depositional environment. Additionally, it must also be emphasized that we have interpreted the environment of deposition, in part, by also considering the relative stratigraphic position of the lithofacies with respect to underlying and overlying strata. Where not directly in contact with basement, facies RB6 overlies shallow marine strata of facies RB5. Overlying strata comprise up to $43 \mathrm{~m}$ of quartz arenites of the Glen Falls Formation, which were deposited in a shallow marine, high-energy barrier island complex (Tanoli and Pickerill, 1987).

The generally fine-grained strata of facies RB6, the presence of marine body fossilsand diffuse bioturbation, and the pervasive occurrence of glauconies together suggest deposition in a relatively low-energy, shallow marine environment. We therefore suggest, based on these observations together with comparison with previously described modern and ancient analogues (e.g., Reinson, 1984; Elliott, 1986; Ward and Ashley, 1989, and references therein), that facies RB6 was deposited in a backbarrier or lagoonal environment (cf. Nance, 1987) of probable uneven width and depth. Within such a generally low-energy environment, interbedded shales and wavy, rippled and lenticular siltstones or fine-grained sandstones are considered to reflect 'fair-weather' wave- and current-related background conditions of sedimentation. Coarser grained, normally graded, parallellaminated and amalgamated grey sandstones or pebbly sandstones presumably reflect episodic higher energy conditions, perhaps as a result of storm activity. Andrews (1970), amongst others, has described similar lagoonal sandstones that he interpreted as storm-related washover sheet deposits (see also Reinson, 1984; Ward and Ashley, 1989). Schwartz (1975) has also recorded the presence of alternating light and dark horizontal laminae, similar to those observed at Hanford Brook, from proximal washover deposits. We consider the source of these relatively mature strata to have been the barrier island complex, remnants of which now constitute the Glen Falls Formation. Possible fluvial influence is presentat both Lancaster Street in the city of Saint John and at Catons Island. At these locations the red, poorly sorted and immature volcanogenic sandstones contrast markedly with the grey and maroon sandstones as interpreted above. The obvious lack of reworking and the textural immaturity of these sandstones suggest rapid deposition from a landward rather than seaward source. The associated fining-and thinningupward sequences at Catons Island may, under such circum- stances, represent deposits reflecting waning flood conditions or increased distance from source as a result of continued transgression. Repeated cycles may represent progradational events associated with temporary sea-level stands and, or, basement uplift.

\section{EARLY CAMBRIAN BASINAL DEVELOPMENT}

In southem New Brunswick, the Ratcliffe Brook Formation comprises the basal sub-trilobitic stratigraphic unit of the Saint John Group, an essentially platformal sequence of Cambrian to Early Ordovician age that forms a small fragment of the Avalon Terrane of Williams and Hatcher (1983). Palaeozoic strata of this terrane contain an Acado-Baltic shelly fauna and most authors have placed it in high $\left(>40^{\circ}\right)$ palaeolatitudes on the southern margin of the Iapetus ocean at least during the Early Palaeozoic (Nance, 1987).

Geological maps of the Saint John region (e.g., Alcock, 1938; Currie, 1984, 1986) illustrate that the Ratcliffe Brook Formation, and the Saint John Group in general, are presently exposed in a series of en echelon northeast-trending, tightly folded 'basins' (Currie, 1984). As noted previously, these 'basins' are faulted on their northwestern sides by southeastdipping high-angle reverse faults (Currie, 1984) and are separated by topographically higher ground underlain by older Precambrian strata. It is perhaps this distribution in isolated 'basins' that prompted Bailey (1879) to suggest that the Saint John Group was originally deposited in isolated trough-like sedimentary basins, a conclusion also reiterated by Hayes and Howell (1937). Alternatively, however, Alcock (1938, p. 16) emphasized that the sequence was originally more geographically widespread and most strata had been removed by subsequent erosion. The remarkable similarity and uniformity in both thickness and lithology of all formations overlying the Ratcliffe Brook Formation suggests that a single depositional basinal model is more tenable (cf. Currie, 1984). The considerable variation in lithology, thickness and lithofacies development of the Ratcliffe Brook Formation suggests that in its early phases of development, different portions of this basin were subject to varying depositional histories.

Deposition of the Ratcliffe Brook Formation occurred initially as a consequence of the early Cambrian eustatic sea-level rise (Vail et al., 1977; Brasier, 1980; Hallam, 1981), a result of combined deglaciation and increase in the volume of oceanic ridges due to rifting or break-up of a late Precambrian Pangea (Worsley etal., 1984). This transgressive, pre-trilobite, event has been documented in several portions of the Avalon Terrane (see Landing, 1988; Landing et al., 1989). Indeed, coeval sequences from Newfoundland, Cape Breton and eastern Massachusetts have been interpreted by Landing (1988) as a result of easterly

Fig. 7. (a) Bidirectional cross-laminated sets (arrowed) within amalgamated sandstones of facies RB5a. Dark arrow indicates internal erosion surface. Location, Hanford Brook; pencil is $13.5 \mathrm{~cm}$ in length. (b) Horizontally laminated, amalgamated sandstones of facies RB5a with internal erosion surfaces (e.g., arrowed). Note that in the lower beds laminae are defined by quartz granule-rich and -poor layers. Location, Hanford Brook; hammer is $32 \mathrm{~cm}$ in length. 

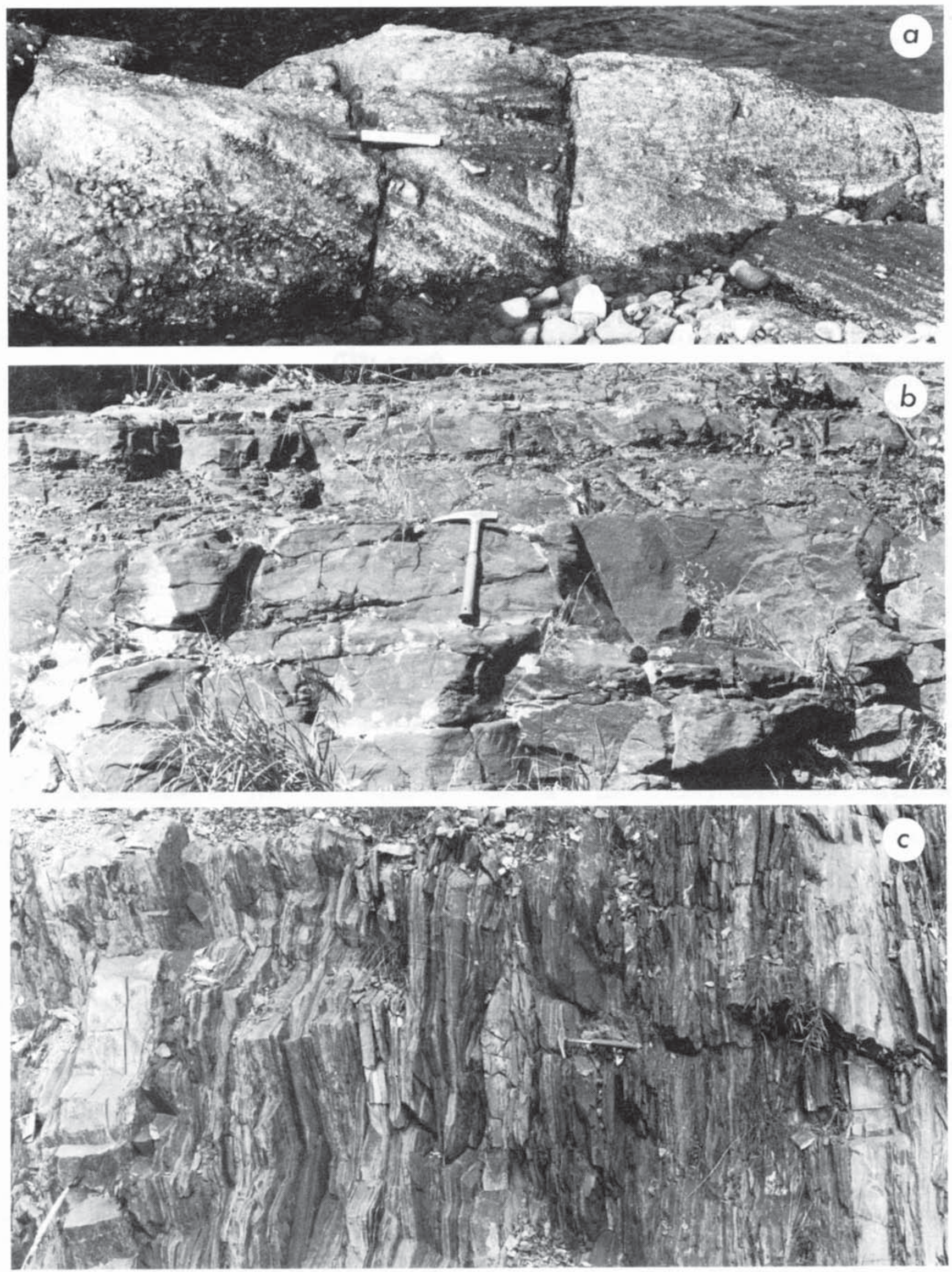
and, or, southerly overlap onto basement during this transgression. The Ratcliffe Brook Formation clearly records evidence of this transgression as, for example, at Hanford Brook (Fig. 2), the sequence comprises alluvial, through shallow marine through lagoonal strata, followed in turn by strata representing a barrier island (Glen Falls Formation) and then by open marine strata of the Hanford Brook Formation (Tanoli and Pickerill, 1988).

In detail, however, it is evident that the Ratcliffe Brook Formation exhibits considerable variation in its temporal and spatial development. There is a marked contrast in thickness and lithofacies development between the area from Mystery Lake northeastwards to Hanford Brook (Fig. 1) and the area around the city of Saint John and in the Long Reach. The Mystery Lake and Hanford Brook sections (Fig. 2) record evidence of the initial transgressive event (facies RB1) followed by a reasonably complete record (facies RB2-RB5a inclusive) of nearshore shallow marine conditions and, at Hanford Brook, tidally reworked distributary channels (facies RB5b). Outcrop on Ratcliffe Brook, which is located between Mystery Lake and Hanford Brook, exposes the stratotype of the formation, which is heavily vegetated, discontinuously exposed and structurally disrupted, thus precluding construction of a meaningful observational and interpretive stratigraphic column. Nevertheless, our observations at Ratcliffe Brook suggest that both the thickness and lithofacies of the formation are similar to those at both Mystery Lake and Hanford Brook.

In contrast, the Ratcliffe Brook Formation in and around the city of Saint John and in the Long Reach consists of thinner sequences and shows only lagoonal strata of lithofacies RB6 (Fig. 2) and underlying nearshore and shallow marine strata of facies RB2-RB5 are notably absent. This suggests that during the initial transgression, Saint John and the Long Reach remained positive areas whereas the region between Mystery Lake and Hanford Brook was submerged. Interestingly, in this context even Walcott (1900) had previously concluded that the lowermost marine portions of the Ratcliffe Brook Formation at Hanford Brook (herein presumably facies RB2-RB5) were never deposited in the Saint John area, though this conclusion was overlooked by subsequent workers in the region. With continued transgression, all areas of the region were eventually submerged so that lagoonal strata of facies RB6 were deposited and are now exposed throughout the region in each of the 'basins' of Bailey (1879).

With respect to the most completely exposed and thickest sequence, that at Hanford Brook, we also note that although strata of the Ratcliffe Brook Formation undoubtedly provide a record of the early Cambrian transgression previously noted from other Avalonian sequences in the eastern United States and Canada, there is also evidence of shoreline progradation. Evidence of this progradational event, as represented by facies RB $5 \mathrm{~b}$ (Fig. 10), is not present at Mystery Lake or Ratcliffe Brook, but we consider this to reflect the absence of suitable exposure. Causes of this progradational event are impossible to assess realistically; a stillstand in sea-level, slight regression, basement uplift and concomitant increased sediment supply, or combinations of these alternatives may be equally possible.

Available palaeocurrent data from the Ratcliffe Brook Formation is limited essentially as a consequence of poor, overgrown and, or, two-dimensional exposure, and must be interpreted with caution. At Hanford Brook, channel axes of facies RB1 are oriented essentially east-west, wave-ripple crests of facies RB2 are oriented north-south and cross-laminated sets in facies RB5 dip to the northeast and mainly to the southwest (Fig. 11). Polymodal distributions such as this are, however, typical of coastal regions where rivers debouch into areas affected by waves and, or, tides (Miall, 1984). Additionally, of course, the data were obtained from separate lithofacies, each formed at a different time and in a different environment. As noted above, Landing (1988) suggested easterly or southerly overlap onto basement during the early Cambrian transgression. Collectively, data from the Ratcliffe Brook Formation would support a broadly easterly overlap but this conclusion must remain tentative.

\section{DISCUSSION, SUMMARY AND CONCLUSIONS}

Perhaps the two most conspicuous attributes of the Ratcliffe Brook Formation are its predominantly red colouration and its high detrital mica content. As previously noted, Hayes and Howell (1937) erroneously considered the sequence to be terrestrial, presumably as a result of its predominant purple-maroonred colour. The red colouration of the strata results from pigmentation by what we presume to be hematite, and not its less stable dimorph maghemite, dispersed throughout as matrix or cement as interstitial aggregates, or as overgrowths surrounding individual quartz particles. As pointed out by Van Houten (1968) there is no reliable method of categorically determining if the hematite pigment was inherited from soils at the source, derived from limonite formed in transit or at the site of deposition, or is diagenetic (see also Berner, 1971). Although typical of terrestrial strata, redbeds are also commonly formed in marginal marine environments similar to that envisaged for formation of much of the Ratcliffe Brook Formation. Ziegler and McKerrow (1975) emphasized that the occurrence of such marine redbeds could be correlated with transgressive events, high rates of sedimentation, availability of a suitably oxidized source area (in the early Cambrian, prior to the development of advanced land plants, a plentiful supply of oxidized iron would have been concentrated during weathering processes), and low organic productivity in the area of accumulation. Several, if not all, of these factors can be applied not only to the Ratcliffe Brook Formation, but also to other Avalonian sub-trilobitic redbed sequences in eastern Massachusetts (Landing, 1988) and southeastern Newfoundland

Fig. 8. (a) Bidirectional trough cross-stratifaction in pebbly sandstones of facies RB5b at Hanford Brook. Marker is $15 \mathrm{~cm}$ in length. (b) Structureless fine-grained sandstone beds of facies RB6. Location, Hanford Brook; hammer is $32 \mathrm{~cm}$ in length. (c) Interbedded shales and sandstones of facies RB6. Location, Somerset Street, city of Saint John; hammer is $32 \mathrm{~cm}$ in length. 

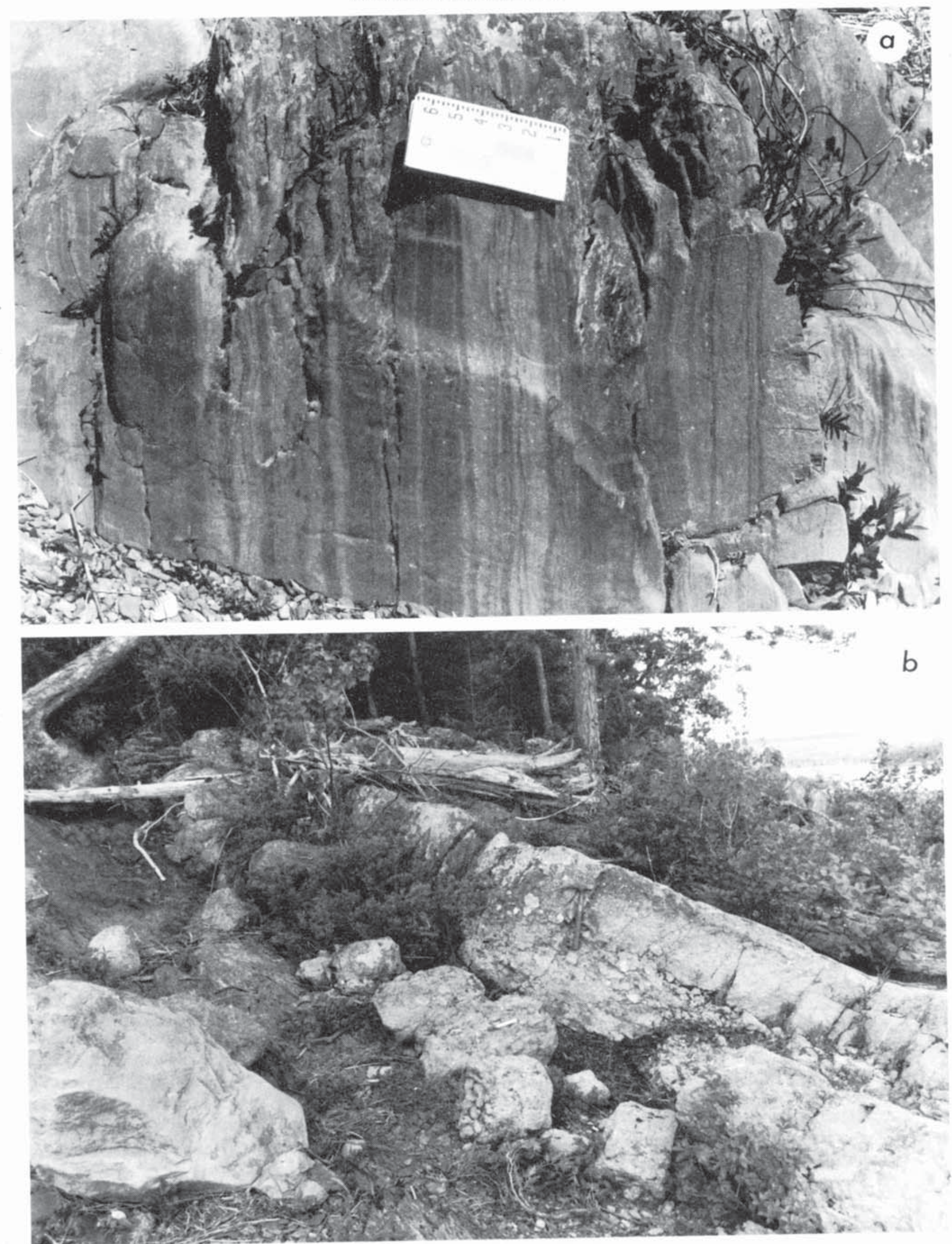

Fig. 9. (a) Interbeds of wavy, flasered and, rarely, lenticular siltstone and shale of facies RB6 at Catons Island. Notebook scale in inches. (b) Massive volcanogenic conglomerate unit constituting the basal portion of a thinning and fining-upward sequence within facies RB6 at Catons Island. Hammer is $32 \mathrm{~cm}$ in length. 


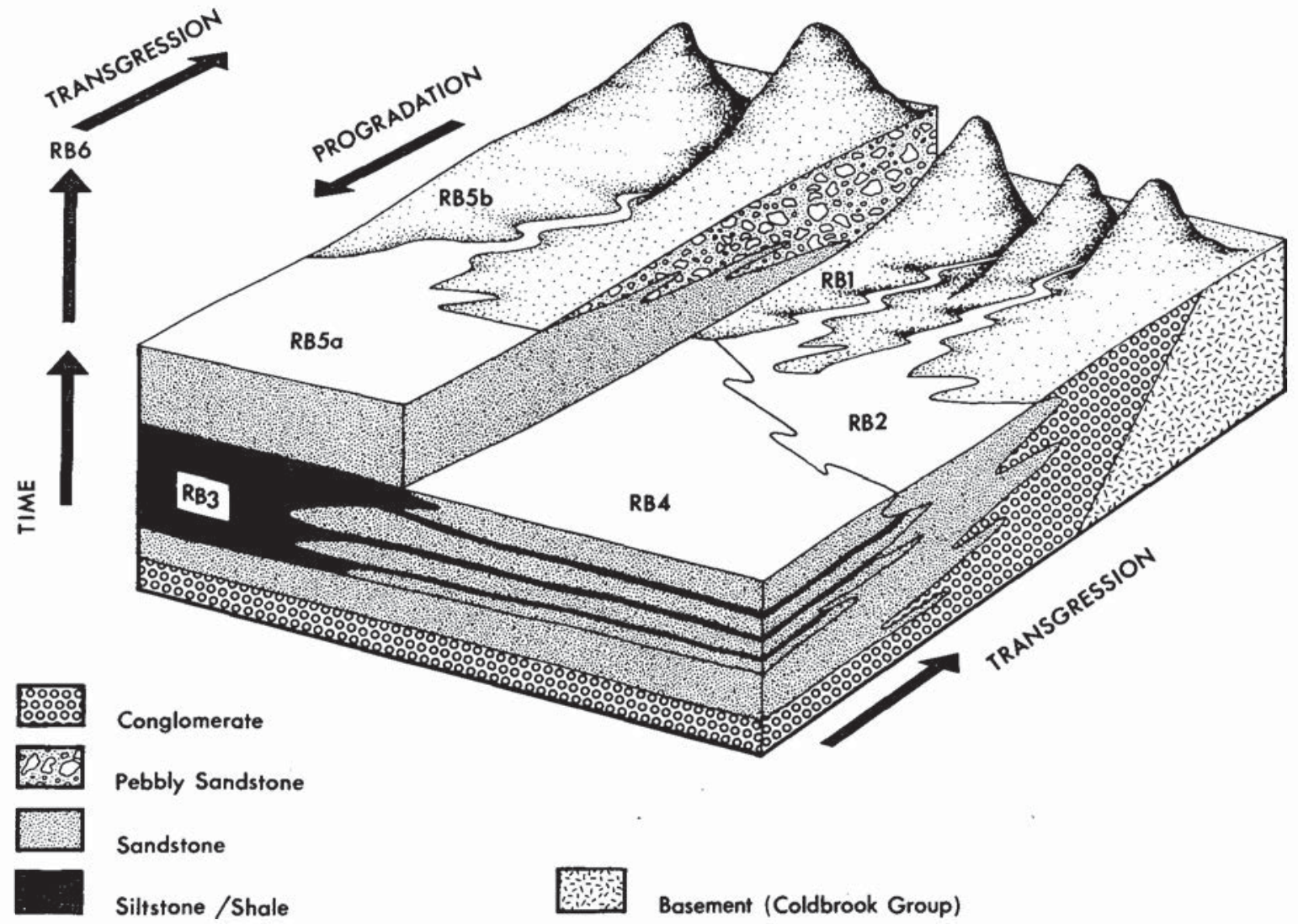

Fig. 10. Schematic diagram illustrating broad environmental interpretation of facies RB1 to RB6 of the Ratcliffe Brook Formation during the early Cambrian marine transgression. Note that facies RB5a is interpreted as resulting from progradation, and that seaward of facies RB6 (but not illustrated) would occur barrier island strata of the Glen Falls Formation.

(Landing et al., 1989).

The presence of abundant detrital micas, essentially muscovite, in the Ratcliffe Brook Formation has been noted by several authors (e.g., McCutcheon, 1987; Tanoli and Pickerill, 1988; Hofmann and Patel, 1989). The occurrence of these micas is of both local and more regional significance. Locally, for example, Tanoli et al. (1985) utilized their presence to distinguish the Ratcliffe Brook Formation from underlying Eocambrian redbeds, which are lithologically similar but contain no detrital micas. The recent report by Dallmeyer and Nance (1989) of a ${ }^{40} \mathrm{Ar} /{ }^{39} \mathrm{Ar}$ plateau age of $615 \pm 2 \mathrm{Ma}$ of muscovites obtained from facies RB6 on Paradise Row in Saint John (Fig. 1) is of more regional significance particularly with respect to their provenance. Late Precambrian volcanic and plutonic rocks that yield similar ages (the Coldbrook Group and the possibly cogenetic Golden Grove suite--see Currie, 1984) are generally devoid of muscovite. Yet the older (Helikian?) Green Head Group (plus the younger Brookville Gneiss and related plutonic rocks), the other potential source of the muscovites, yields a metamorphic age of ca. 540$550 \mathrm{Ma}$ (D. Nance, personal communication, 1989), that is, considerably younger than the age obtained for the detrital muscovites. Though clearly enigmatic, Dallmeyer and Nance (1989) suggested the micas were derived from mylonite zones within the Golden Grove suite, but Barr and White (1989) proposed a source from slivers of mica schist developed within the Coldbrook Group. Irrespective of the specific origin, it is clear that all these authors believe the provenance to have been the Coldbrook Group and related units. This is consistent with the conclusions of Tanoli's (1987) petrographic analysis of the Saint John Group.

Barr and White (1989) have recently suggested that this portion of the Avalon Terrane can be more appropriately subdivided into two terranes that are in faulted contact, namely the Brookville and Caledonia terranes. The former includes the Green Head Group, Brookville Gneiss and associated plutonic units and the latter the Coldbrook Group, Eocambrian units (see Currie, 1988) and the Saint John Group. Because the Brookville Terrane does not appear to have provided detritus to the Ratcliffe Brook Formation, or indeed younger formations of the Saint John Group, it can be suggested that if Barr and White (1989) are correct in their interpretation, then the two terranes were not juxtaposed until at least post-Early Ordovician times. Interestingly, the Saint John Group is only in direct sedimentological contact with the Caledonia Terrane; contacts with units of the Brookville Terrane are consistently faulted.

Although the Ratcliffe Brook Formation has, historically, attracted much attention, particularly with respect to its age, no in-depth analysis of its lithofacies and their depositional environments has, until now, been undertaken. We interpret the sequence to have been deposited initially in a non-marine and latterly, and dominantly, in transitional and shallow marine environments in response to the early Cambrian eustatic marine 


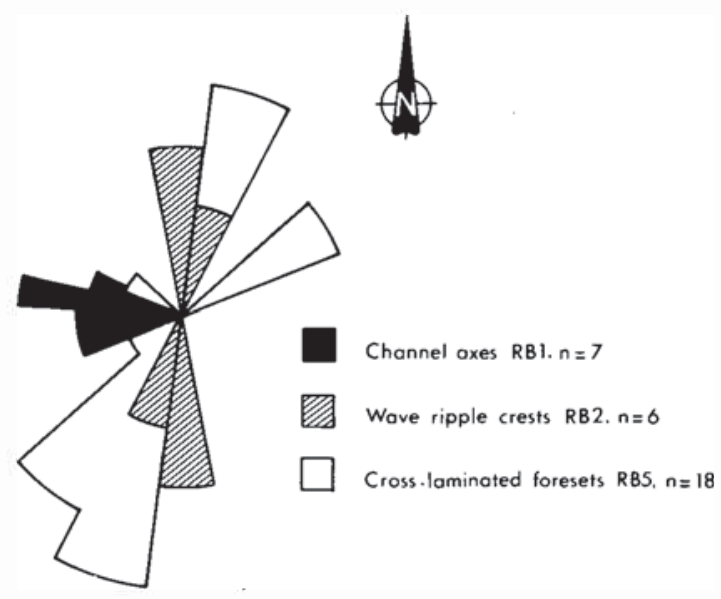

Fig. 11. Rose diagram of palaeocurrent data from the Ratcliffe Brook Formation.

transgression (cf. Patel, 1973; Hofmann and Patel, 1989). Six lithofacies, which in stratigraphically ascending order are termed RB1 to RB6, are recognized in the sequence. Facies RB1, comprising up to $25 \mathrm{~m}$ of generally poorly sorted conglomerates, is interpreted as having been deposited in braid channels associated with distal portions of an alluvial fan, possibly in a coastal setting. Facies RB2-RB4, respectively comprising rippled and non-rippled sandstone (RB2), layered siliceous claystone and fine-grained sandstone (RB3) and greenish-grey chamositic sandstone and siltstone (RB4), are interpreted as shallow subtidal in origin. Facies RB2 to RB4 are possibly lateral facies equivalents, with facies RB3 and RB4 being deposited seaward of facies RB2. Facies RB5 comprises maroon, variably bedded, coarsegrained sandstone and conglomerate interpreted as shallow marine foreshore-shoreface deposits (subfacies RB5a) and as strata deposited in tidally reworked distributary channels (subfacies RB5b). Finally, facies RB6, comprising greenish and maroon shale, siltstone, sandstone and volcanogenic sandstone, is interpreted as a lagoonal deposit, the lagoon probably having been of uneven width and depth and having received sediment by various mechanisms and various local sources. This accounts for the considerable variation in lithology, textural maturity, composition and internal features observed in this facies.

The considerable spatial variation in thickness and facies distribution within the Ratcliffe Brook Formation (Fig. 2), suggests that during the initial early Cambrian transgression the (present-day) area extending from the city of Saint John to the Long Reach remained a positive area, whereas the region between Mystery Lake and Hanford Brook (Fig. 1) was submerged. Thus, facies RB2-RB5 were not deposited in the former area whereas in the latter they are well represented (Fig. 2). Continued transgression resulted in drowning of the entire region and the development of a barrier island and lagoonal system (respectively the Glen Falls Formation and facies RB6 of the Ratcliffe Brook Formation - see Tanoli and Pickerill, 1987). There is no evidence to suggest that the strata were originally deposited in separate sedimentary basins as previously proposed by Bailey (1879) and Hayes and Howell (1937). A single depositional basinal model is more tenable and the present-day distribution of the strata in isolated regions is more a reflection of local tectonics and normal erosional processes.

\section{ACKNOWLEDGEMENTS}

We wish to thank the technical staff at the University of New Brunswick, particularly A. Gomez and R. McCulloch, for their help in all phases of preparation of this manuscript. Rose Northrup and Diane Tabor are thanked for its preparation. Detailed and constructive reviews by Damian Nance and Martin Gibling greatly improved its content. For their assistance, encouragement and stimulating field discussions we thank Ken Currie, Ed Landing, Paul Myrow, Guy Narbonne, Damian Nance and Ismail Patel. Financial support was provided by the Ministry of Education, Govemment of Pakistan, and by a Natural Sciences and Engineering Research Council of Canada operating grant (OGP0003857) to R.K. Pickerill.

AIGNER, T. 1985. Storm depositional systems: dynamic stratigraphy in modem and ancient shallow-marine sequences. Lecture Notes in Earth Sciences, 3, 174 p.

ALCOCK, F.J. 1938. Geology of Saint John Region, New Brunswick. Geological Survey of Canada, Memoir 216,65 p.

ALLEN, J.R.L. 1970. Sediments of the modern Niger Delta: a summary and review. In Deltaic sedimentation - modern and ancient. Edited by J.R. Morgan. Society of Economic Paleontologists and Mineralogists, Special Publication 15, pp. 138-151.

ANDREWS, P.B. 1970. Facies and genesis of a hurricane washover fan, St. Joseph Island, central Texas coast. Bureau of Economic Geology, University of Texas, Austin, Report of Investigation 67, $147 \mathrm{p}$.

BAILEY, L.W. 1879. Report on the pre-Silurian (Huronian) and Cambrian, or Primordial Silurian rocks of southern New Brunswick. Geological Survey of Canada, Report of Progress 1877-78, section DD, pp. 1-34.

BARR, S.M. and WHITE, C.E. 1989. Re-interpretation of Precambrian stratigraphy, King and Saint John counties, New Brunswick. In Project summaries for 1989. Compiled and edited by S.A. Abbott. Minerals and Energy Division, Department of Natural Resources and Energy, New Brunswick, pp. 182-189.

BERNER, R.A. 1971. Principles of chemical sedimentology. McGraw Hill, New York, 240 p.

BLUCK, B.J. 1967. Deposition of some upper old red sandstone conglomerates in the Clyde area: a study in the significance of bedding. Scottish Journal of Geology, 3, pp. 139-167.

BOURGEOIS, J. and LEITHOLD, E.L. 1984. Wave-reworked conglomerates - depositional processes and criteria for recognition. In Sedimentology of Gravels and Conglomerates. Edited by E.H. Koster and R.J. Steel. Canadian Society of Petroleum Geologists, Memoir 10, pp. 331-343.

BRASIER, M.D. 1980. The Lower Cambrian transgression and glauconite - phosphate facies in western Europe. Journal of the Geological Society of London, 137, pp. 695-703.

BRENCHLEY, P.J. and PICKERILL, R.K. 1980. Shallow subtidal sediments of Soudleyan (Caradoc) age in the Berwyn Hills, North Wales, and their palaeogeographic context. Proceedings of the Geological Association, 91, pp. 177-194.

CARTER, C.H. 1978. A regressive barrier and barrier-protected deposit: depositional environment and geographic setting of the Late Tertiary Cohansey sand. Journal of Sedimentary Petrology, 
48, pp. 933-950.

CLIFTON, H.E. 1973. Pebble segregation and bed lenticularity in wave-worked versus alluvial gravel. Sedimentology, 20, pp. 173188.

CLIFTON, H.E., HUNTER, R.E., and PHILLIPS, R.L. 1971. Depositional structures and processes in the non-barred high-energy nearshore. Joumal of Sedimentary Petrology, 41, pp. 651-670.

COTTER, E. 1983. Shelf, paralic, and fluvial environments and eustatic sea-level fluctuations in the origin of the Tuscarora Formation (Lower Silurian) of central Pennsylvania. Journal of Sedimentary Petrology, 53, pp. 25-49.

CRIMES, T.P. 1987. Trace fossils and correlation of late Precambrian and early Cambrian strata. Geological Magazine, 124, pp. 97-119.

CURRIE, K.L. 1984. A reconsideration of some geological relations near Saint John, New Brunswick. Current Research, Part A, Geological Survey of Canada, Paper 84-1A, pp. 193-201.

- 1986. Stratigraphy and Structure of the Avalonian Terrane around Saint John, New Brunswick. Maritime Sediments and Atlantic Geology, 22, pp. 278-295.

- 1988. The western end of the Avalon Zone in southem New Brunswick. Maritime Sediments and Atlantic Geology, 24, pp. 339-352.

CURRIE, K.L. and NANCE, R.D. 1983. A reconsideration of the Carboniferous rocks of Saint John, New Brunswick. Current Research, Part A, Geological Survey of Canada, Paper 83-1A, pp. 29-36.

CURRIE, K.L., NANCE, R.D., PAJARI, G.E., and PICKERILL, R.K. 1981. Some aspects of the pre-Carboniferous geology of Saint John, New Brunswick. Current Research, Part A, Geological Survey of Canada, Paper 81-1A, pp. 23-30.

DAILY, B., MOORE, P.S., and RUST, B.R. 1980. Terrestrial-marine transition in the Cambrian rocks of Kangaroo Island, south Australia. Sedimentology, 27, pp. 379-399.

DALLMEYER, R.D. and NANCE, R.D. $1989 .{ }^{40} \mathrm{Ar} \beta{ }^{9} \mathrm{Ar}$ mineral age record of polyphase tectonothermal activity in the Avalon Terrane of southern New Brunswick. Geological Association of Canada/ Mineralogical Association of Canada, Program with Abstracts, 14. p. A126.

ELLIOTT, T. 1986. Siliciclastic shorelines. In Sedimentary environments and facies, second edition. Edited by H.G. Reading. Blackwell, Oxford, pp. 155-188.

GJELBERG, J. and STEEL, R. 1983. Middle Carboniferous marine transgression, Bjornoya, Svalbard: facies sequences from an interplay of sea level changes and tectonics. Geological Journal, 18, pp. 1-19.

GLOPPEN, T.G. and STEEL, R.J. 1981. The deposits, internal structure and geometry of six alluvial fan - fan delta bodies (Devonian, Norway) - a study in the significance of bedding sequence in conglomerates. In Non-marine deposits - models for exploration. Edited by F.G. Ethridge. Society of Economic Paleontologists and Mineralogists, Special Publication 31, pp. 49. 69.

HALLAM, A. 1981. Facies interpretation and the stratigraphic record. W.H. Freeman and Company, Oxford, 291 p.

HAYES, A.O. and HOWELL, B.F. 1937. Geology of Saint John, New Brunswick. Geological Society of America, Special Paper 5, 146 p.

HAYES, M.O. 1979. Barrier island morphology as a function of tidal and wave regime. In Barrier islands - from the Gulf of St. Lawrence to the Gulf of Mexico. Edited by S.P. Leatherman. Academic Press, New York, pp. 1-27.

HOFMANN, H.J. and PATEL, I.M. 1989. Trace fossils from the type
'Etcheminian Series' (Lower Cambrian Ratcliffe Brook Formation), Saint John area, New Brunswick, Canada. Geological Magazine, 126, pp. 139-157.

HOWARD, J.D. and REINECK, H.-E. 1981. Depositional facies of a 'high energy' beach-to-offshore sequence and their comparison with a low energy sequence. Bulletin of American Association of Petroleum Geologists, 65, pp. 807-830.

IRELAND, B.J., CURTIS, C.D., and WHITEMAN, J.A. 1983. Compositional variation within some glauconites and illites and implications for their stability and origin. Sedimentology, 30, pp. 769 786.

LANDING, E. 1988. Lower Cambrian of eastem Massachussetts: stratigraphy and small shelly fossils. Journal of Paleontology, 62 , pp. 661-695.

LANDING, E., MYROW, P., BENUS, A.P., and NARBONNE, G.M. 1989. The Placentian Series: appearance of the oldest skeletalized faunas in southeastern Newfoundland. Journal of Paleontology, 63, pp. 739-769.

LEITHOLD, E.L. and BOURGEOIS, J. 1984. Characteristics of coarse-grained sequences deposited in nearshore, wave-dominated environments - examples from the Miocene of south-west Oregon. Sedimentology, 31, pp. 749-775.

LEVELL, B.K. 1980. Evidence for currents associated with waves in Late Precambrian shelf deposits from Finnmark, North Norway. Sedimentology, 27, pp. 153-166.

MATTHEW, G.F. 1889. On Cambrian organisms in Acadia. Transactions of the Royal Society of Canada, Section 4, 7, pp. 135-162.

. 1899a. A Palaeozoic terrane beneath the Cambrian. Annals of the New York Academy of Sciences, 12, pp. 41-56.

- 1899b. The Etcheminian fauna of Smith Sound, Newfoundland. Transactions of the Royal Society of Canada, Section 5, 4, pp. 97-119.

- 1899c. Preliminary notice of the Etcheminian fauna of Newfoundland. Bulletin of the Natural Historical Society of New Brunswick, 18, pp. 189-196 (issued in 1902).

McBRIDE, E.F., WEIDIE, A.E., and WOLLEBEN, J.A. 1975. Deltaic and associated deposits of the Difunta Group (Late Cretaceous to Palaeocene), Parras and La Popa Basins, northeastem Mexico. In Deltas, models for exploration. Edited by M.L. Broussard. Houston Geological Society, Houston, pp. 485-522.

McCUBBIN, D.G. 1982. Barrier-island and strand-plain facies. In Sandstone depositional environments. Edited by P.A. Scholle and D.R. Spearing. American Association of Petroleum Geologists, Memoir 31, pp. 247-280.

McCUTCHEON, S.R. 1987. Cambrian stratigraphy in the Hanford Brook area, southem New Brunswick, Canada. In Centennial Field Guide, Volume 5. Edited by D.C. Roy. Northeastern Section of the Geological Society of America, pp. 399-402.

McCUTCHEON, S.R. and RUITENBERG, A.A. 1984. Geology, Saint John, New Brunswick. New Brunswick Department of Natural Resources, Mineral Resources Division, Plate 84-17.

McCUTCHEON, S.R., McLEOD, M.J., and RUITENBERG, A.A. 1982. Southem New Brunswick. In Guidebook for Avalon and Meguma zones. Compiled by A.F. King. IGCP Project 27, NATO advanced study institute, Report 9, pp. 277-284.

MIALL, A.D. 1984. Principles of Sedimentary Basin Analysis. SpringVerlag, New York, Berlin, Heidelberg, Tokyo, 490 p.

NANCE, R.D. 1987. Model for the Precambrian evolution of the Avalon terrane in southern New Brunswick, Canada. Geology, 15, pp. 753-756.

NEMEC, W. and STEEL, R.J. 1984. Alluvial and coastal conglomerates: their significant features and some comments on gravelly 
mass-flow deposits. In Sedimentology of Gravels and Conglomerates. Edited by E.H. Koster and R.J. Steel. Canadian Society of Petroleum Geologists, Memoir 10, pp. 1-31.

O'BRIEN, S.J., WARDLE, R.J., and KING, A.F. 1983. The Avalon Zone: A pan-African terrane in the Appalachian Orogen of Canada. Geological Journal, 18, pp. 195-222.

ODIN, G.S. and LETOLLE, R. 1980. Glauconitization and phosphatization environments: a tentative comparison. In Marine phosphorites - geochemistry, occurrence, genesis. Edited by Y.K. Bentor. Society of Economic Paleontologists and Mineralogists, Special Publication 29, pp. 227-237.

ODIN, G.S. and MATTER, A. 1981. De glauconianum originae. Sedimentology, 28, pp. 611-641.

PATEL, I.M. 1973. Sedimentology of the Ratcliffe Brook Formation (Lower Cambrian?) in southeastern New Brunswick. Geological Society of America, 8th Annual Meeting, Northeastem Section, Abstracts with Programs, 5, pp. 206-207.

PORRENGA, D.H. 1967. Glauconite and chamosite as depth indicators in the marine environment. Marine Geology, 5, pp. 493-499.

RAST, N. and SKEHAN, S.J., J.W. 1983. The evolution of the Avalonian Plate. Tectonophysics, 100, pp. 257-286.

RAST, N., O'BRIEN, B.H., and WARDLE, R.J. 1976. Relationships between Precambrian and lower Paleozoic rocks of the "Avalon Platform' in New Brunswick, the northeast Appalachians and the British Isles. Tectonophysics, 30, pp. 315-338.

REINSON, G.E. 1984. Barrier island and associated strand-plain systems. In Facies models, second edition. Edited by R.G. Walker. Geoscience Canada, Reprint Series 1, pp. 119-140.

RUST, B.R. and KOSTER, E.H. 1984. Coarse alluvial deposits. In Facies models, second edition. Edited by R.G. Walker. Geoscience Canada, Reprint Series 1, pp. 53-69.

SCHWARTZ, R.K. 1975. Nature and genesis of some storm washover deposits. U.S. Army, Corps of Engineers, Coastal Engineering Research Center, Technical Memorandum 61, 69 p.

TANOLI, S.K. 1987. Stratigraphy, sedimentology, and ichnology of the Cambrian-Ordovician Saint John Group, southem New Brunswick, Canada. Unpublished Ph.D. thesis, University of New Brunswick, Fredericton, $436 \mathrm{p}$.

TANOLI, S.K. and PICKERILL, R.K. 1987. The Glen Falls Formation - an example of a barrier island retreated by shoreface erosion. Geological Bulletin of the University of Peshawar, 20, pp. 1-21. . 1988. Lithostratigraphy of the Cambrian-Lower Ordovician Saint John Group, southern New Brunswick. Canadian Journal of Earth Sciences, 25, pp. 669-690.

1989. Cambrian shelf deposits of the King Square Formation, Saint John Group, southem New Brunswick. Atlantic Geology, 25. pp. 129-141.

TANOLI, S.K., PICKERILL, R.K., and CURRIE, K.L. 1985. Distinction of Eocambrian and Lower Cambrian redbeds, Saint John area, southern New Brunswick. Current Research, Part A, Geological Survey of Canada, Paper 85-1A, pp. 699-702.

VAIL, P.R., MITCHUM, R.M., Jr., and THOMPSON, S. 1977. Seismic stratigraphy and global changes of sea level, part 4: global cycles of relative changes of sea level. In Seismic stratigraphy applications to hydrocarbon exploration. Edited by C.E. Payton. American Association of Petroleum Geologists, Memoir 26, pp. 83-97.

VAN HOUTEN, F.B. 1968. Iron oxides in red beds. Bulletin of the Geological Society of America, 79, pp. 399-416.

VAN HOUTEN, F.B. and PURUCKER, M.E. 1984. Glauconitic peloids and chamositic ooids - favorable factors, constraints, and problems. Earth Science Reviews, 20, pp. 211-243.

WALCOTT, C.D. 1900. Lower Cambrian terrane in the Atlantic Province. Proceedings of the Washington Academy of Sciences, 1, pp. 301-339.

WARD, L.G. and ASHLEY, G.M., editors. 1989. Physical processes and sedimentology of siliciclastic-dominated lagoonal systems. Marine Geology, 88, pp. 181-364.

WARDLE, R.J. 1978. The stratigraphy and tectonics of the Green Head Group; its relation to Hadrynian and Palaeozoic rocks, southem New Brunswick. Unpublished Ph.D. thesis, University of New Brunswick, Fredericton, New Brunswick, 294 p.

WESCOTT, W.A. and ETHRIDGE, F.G. 1980. Fan-delta sedimentology and tectonic setting - Yallahs fan-delta, southeast Jamaica. Bulletin of the American Association of Petroleum Geologists, 64 , pp. 374-399.

WILLIAMS, H. 1964. The Appalachians in northeastern Newfoundland - a two-sided symmetrical system. American Joumal of Science, 262, pp. 1137-1158.

WILLIAMS, H. and HATCHER, R.D. 1983. Appalachian suspect terranes. In Contributions to the tectonics and geophysics of mountain chains. Edited by R.D. Hatcher, H. Williams and I. Zietz. Geological Society of America, Memoir 158, pp. 33-53.

WILSON, R.F. 1958. Sedimentary facies of the Moenkopi Formation of Triassic age on the Colorado Plateau. Bulletin of the Geological Society of America, Abstracts, 69, p. 1749.

WORSLEY, T.R., NANCE, D., and MOODY, J.B. 1984. Global tectonics and eustasy for the past 2 billion years. Marine Geology, 58, pp. 373-400.

ZIEGLER, A.M. and McKERROW, W.S. 1975. Silurian marine red beds. American Journal of Science, 275, pp. 31-56. 